\title{
Deu anys de seguiment demogràfic i genètic d'Stachys maritima a Catalunya (2001-2010). Implicacions per a un pla de recuperació
}

\author{
C. BLANCHÉ ${ }^{1}$, C. BARRIOCANAL ${ }^{2}$, M. C. MARTINELL ${ }^{1}$, S. MASSÓ $^{1}$ \& J. LÓPEZ-PUJOL ${ }^{3}$ \\ ${ }^{1}$ BioC-GReB, Institut de Recerca de la Biodiversitat, Laboratori de Botànica, Facultat de Farmàcia, Universitat de \\ Barcelona, Avda. Joan XXIII s/n., 08028 Barcelona, Catalunya, Espanya \\ ${ }^{2}$ Grup de Recerca en Medi Ambient i Tecnologies de la Informació Geogràfica, Institut de Medi Ambient, Universitat \\ de Girona, Plaça Ferrater Mora 1, 17001 Girona, Catalunya, Espanya \\ ${ }^{3}$ BioC-GReB, Institut Botànic de Barcelona (CSIC-ICUB), Psg. del Migdia s/n., 08038 Barcelona, Catalunya, Espanya
}

Autor per a correspondència: C. Blanché (cesarblanche@ub.edu)

Rebut 28 octubre 2010; Acceptat 16 novembre 2010

\begin{abstract}
Ten years of demographic and genetic monitoring of Stachys maritima in Catalonia (2001-2010). Implications for a recovery plan.- Stachys maritima is a species typical of the coastal dunes, with a wide distribution within the Mediterranean Basin. In spite of this, the species shows a clear regression. In Catalonia, it has been observed an important reduction of its populations since early 20th century, where it has disappeared from several localities in which it was relatively common (Tarragonès, Barcelonès). Herein we present the results of the demographic monitoring of the species during the last 10 years (2001-2010) in the known localities in Catalonia. Besides corroborating the disappearance (northern Sant Martí d'Empúries), the re-discovering (Llobregat Delta beach) and the detection of new populations (inner dunes of the Montgrí), a large year-to-year fluctuation of the monitored populations is stated; the possible reasons are discussed. In addition, the present work also includes the results of the allozyme diversity analysis of the new detected populations as well as the rediscoveries of the period 2004-2008, which were not included in a former study of genetic diversity carried out in 2002-2003. It is necessary to emphasize that the contribution of the new populations to the genetic diversity of Stachys maritima is very small, which can be attributed to their limited population size and /or to founder effects.

Despite that the species is included in the Annex 2 ("En Perill d'Extinció") within the Catàleg de Flora Amenaçada de Catalunya (Catalogue of Endangered Flora of Catalonia), and some "soft" conservation measures have been applied at local level (signposting of the beach accesses, environmental education, etc.) coupled with other more significant measures (e.g. translocation of individuals discovered in an artificial sandbank), it would be necessary the coordinated action and the scientific support of any initiative of conservation that could be carried out. The general frame to initiate actions of conservation should be the recovery plan of Stachys maritima, whose draft and application is mandatory in accordance to the Catàleg.
\end{abstract}

Key words: Catalonia; conservation; dunes; extinction; fragmentation; invasive species.

\section{Resumen}

Diez años de seguimiento demográfico y genético de Stachys maritima en Catalunya (2001-2010). Implicaciones para un plan de recuperación.- Stachys maritima es una especie característica de dunas litorales, con una amplia área de distribución en el Mediterráneo. A pesar de ello, la especie muestra una clara regresión. En Catalunya se ha observado una importante reducción de sus poblaciones desde principios del siglo XX, donde ha desaparecido de diversas localidades en las que era relativamente abundante (Tarragonès, Barcelonès). Se presentan los resultados del seguimiento demográfico de la especie durante los últimos 10 años (2001-2010) en las localidades conocidas en Catalunya. Al margen de corroborar la desaparición de algunos núcleos (núcleo norte de Sant Martí d'Empúries), el redescubrimiento de otros (playa del Delta del Llobregat) o la detección de nuevas poblaciones (dunas interiores del Montgrí), se constata una gran fluctuación interanual de los núcleos monitorizados, las posibles causas de la cual se discuten detenidamente. Por otro lado, el presente trabajo incluye también los resultados del análisis de la diversidad 
isoenzimática de las nuevas poblaciones detectadas así como los redescubrimientos del periodo 2004-2008, que no se habían incluido en los estudios de diversidad genética de los años 2002-2003. Cabe destacar que la contribución de los nuevos núcleos a la diversidad genética de Stachys maritima es muy pequeña y se puede atribuir a su reducido tamaño poblacional y/o a efectos fundadores.

A pesar que la especie se ha incluido en el Anexo 2 ("En Perill d'Extinció") del Catàleg de Flora Amenaçada de Catalunya, y que a escala local se han realizado algunas medidas de conservación "blandas" (señalización de los accesos a la playa, educación ambiental, etc.), junto a otras medidas más significativas pero realizadas con carácter de urgencia (p. ej. la translocación de individuos descubiertos en un arenal), sería necesario la acción coordinada y el apoyo científico de cualquier iniciativa de conservación que se lleve a cabo. El marco general para iniciar acciones de conservación debería ser el plan de recuperación de Stachys maritima, la redacción y aplicación del cual es preceptiva, tal y como consta en el Catàleg.

Palabras clave: Catalunya; conservación; dunas; especies invasoras; extinción; fragmentación.

\begin{abstract}
Resum
Deu anys de seguiment demogràfic i genètic d'Stachys maritima a Catalunya (2001-2010). Implicacions per a un pla de recuperació.- Stachys maritima és una espècie característica de dunes litorals, amb una àmplia àrea de distribució a la Mediterrània. Malgrat això, la planta sembla estar en clara regressió. A Catalunya, s'ha observat un declivi significatiu des de principis del s. XX, i ha desaparegut de moltes localitats on era relativament abundant (Tarragonès, Barcelonès). Es presenten els resultats del seguiment demogràfic de l'espècie durant els darrers deu anys (2001-2010) a totes les localitats conegudes a Catalunya. A banda de constatar la desaparició d'algun dels nuclis (nucli nord de Sant Martí d'Empúries), el redescobriment d'altres (platja del Prat de Llobregat) o la troballa de noves poblacions (dunes interiors del Montgrí), es constata una gran fluctuació interanual dels diferents nuclis poblacionals monitoritzats, les possibles causes de la qual es discuteixen detingudament. D'altra banda, aquest treball també inclou els resultats de l'anàlisi de la diversitat isoenzimàtica de les noves troballes i/o redescobriments durant el període 2004-2008, i que no havien estat per tant inclosos en l'estudi de diversitat genètica dut a terme durant els anys 2002-2003. La contribució dels nous nuclis a la diversitat genètica d'Stachys maritima és molt petita, que pot atribuir-se a la reduïda mida poblacional i/o a efectes fundadors.

Tot i que l'espècie ha estat inclosa dins l'Annex 2 (“En Perill d'Extinció") del Catàleg de Flora Amenaçada de Catalunya, i a nivell local s'han dut a terme algunes mesures de conservació "toves" (senyalització d'accessos a les platges, educació ambiental, etc.) juntament amb d'altres mesures amb més significació però amb un caràcter d'urgència ( $p$. ex. la translocació d'individus descoberts en una sorrera), seria necessari l'acció coordinada i el suport científic de qualsevol iniciativa de conservació que es dugui a terme. El marc genèric per a endegar qualsevol acció de conservació hauria d'ésser el pla de recuperació d'Stachys maritima, la redacció i aplicació del qual és preceptiva d'acord amb el que estableix el Catàleg.
\end{abstract}

Paraules clau: Catalunya; conservació; dunes; espècies invasores; extinció; fragmentació.

\section{INTRODUCCIÓ}

Stachys maritima Gouan (Fig. 1) és un hemicriptòfit propi de dunes litorals (i, més rarament, interiors), àmpliament distribuït per la conca Mediterrània, des del litoral ibèric fins a la zona del mar Negre i des de Turquia fins a Algèria, trobant-se a faltar a les Balears, Sardenya i Sicília però no a Còrsega (Greuter et al., 1986) (Fig. 2). La seva biologia reproductiva indica que és una espècie al·lògama parcialment autocompatible. Floreix majoritàriament entre maig i juliol i la seva fructificació es produeix entre juny i agost (Molero et al., 2007), tot $\mathrm{i}$ que en condicions favorables pot florir fins $\mathrm{i}$ tot en ple hivern (C. Blanché et al., obs. pers.). No es disposa d'una avaluació de l'estat de conservació de l'espècie a escala mundial, però sí per a l'estat espanyol (CR) i per a Catalunya (EN) (Taula 1).
La distribució actual d'Stachys maritima a la península Ibèrica es limita a la costa nord-est de Catalunya, i ha patit una forta regressió en les darreres dècades, documentada a la recopilació de Barriocanal \& Blanché (2002) (Fig. 3). Amb posterioritat, diverses campanyes de prospecció han permès d'actualitzar l'estat de coneixement sobre distribució i efectius. Així, en alguns indrets d'on es tenia constància de l'espècie, com ara les platges de Salou i Tarragona (Fig. 3) a la dècada dels anys 20 del segle passat (Barriocanal \& Blanché, 2002), no hi ha estat retrobada, tot i les intensives prospeccions recents. Al delta del Llobregat, 1'espècie era considerada molt abundant als anys 20 del s. XX, i sembla que encara ho era prou als 50 (Barriocanal \& Blanché, 2002); a partir de llavors devia iniciar-se un procés accelerat de rarificació fins a la seva gairebé extinció al Baix 

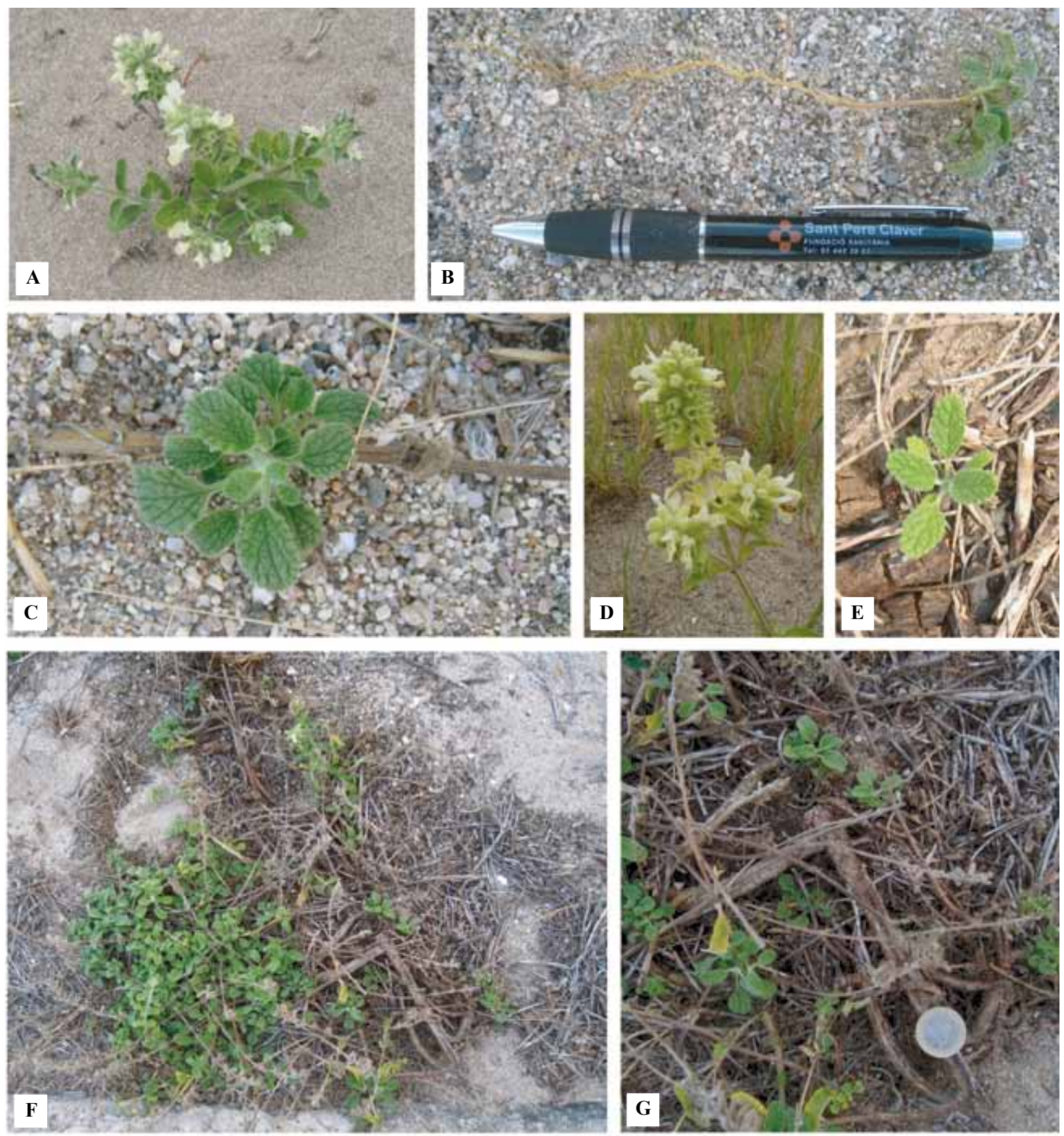

Figura 1. Diversos detalls d'Stachys maritima: (A), aspecte general d'un individu reproductor; (B), aspecte d'una arrel desenterrada; (C), rebrot a partir d'un rizoma; (D), detall de les flors; (E), germinació; (F) i (G), individu longeu (a la dreta, detall de la mida del rizoma). [Fotografies: (A) i (E), J. López-Pujol; (B), (C), (D), (F) i (G), S. Massó].

Llobregat (la darrera citació de l'espècie correspon a un plec d'herbari de 1973). Tot i això, un plec d'herbari de 1992 va testimoniar novament la presència del tàxon a la platja del Prat (Baix Llobregat) als anys 90, malgrat que va passar inadvertida al camp durant un cert temps (del Hoyo et al., 2006). Aquesta troballa va originar una recerca intensiva, infructuosa fins al moment de la detecció d'un únic peu, l'any 2006 (del Hoyo et al., 2006). Des d'aleshores, diversos investigadors han fet un seguiment detallat de la població, que s'ha mantingut sempre, fins ara, al llindar de la desaparició. 


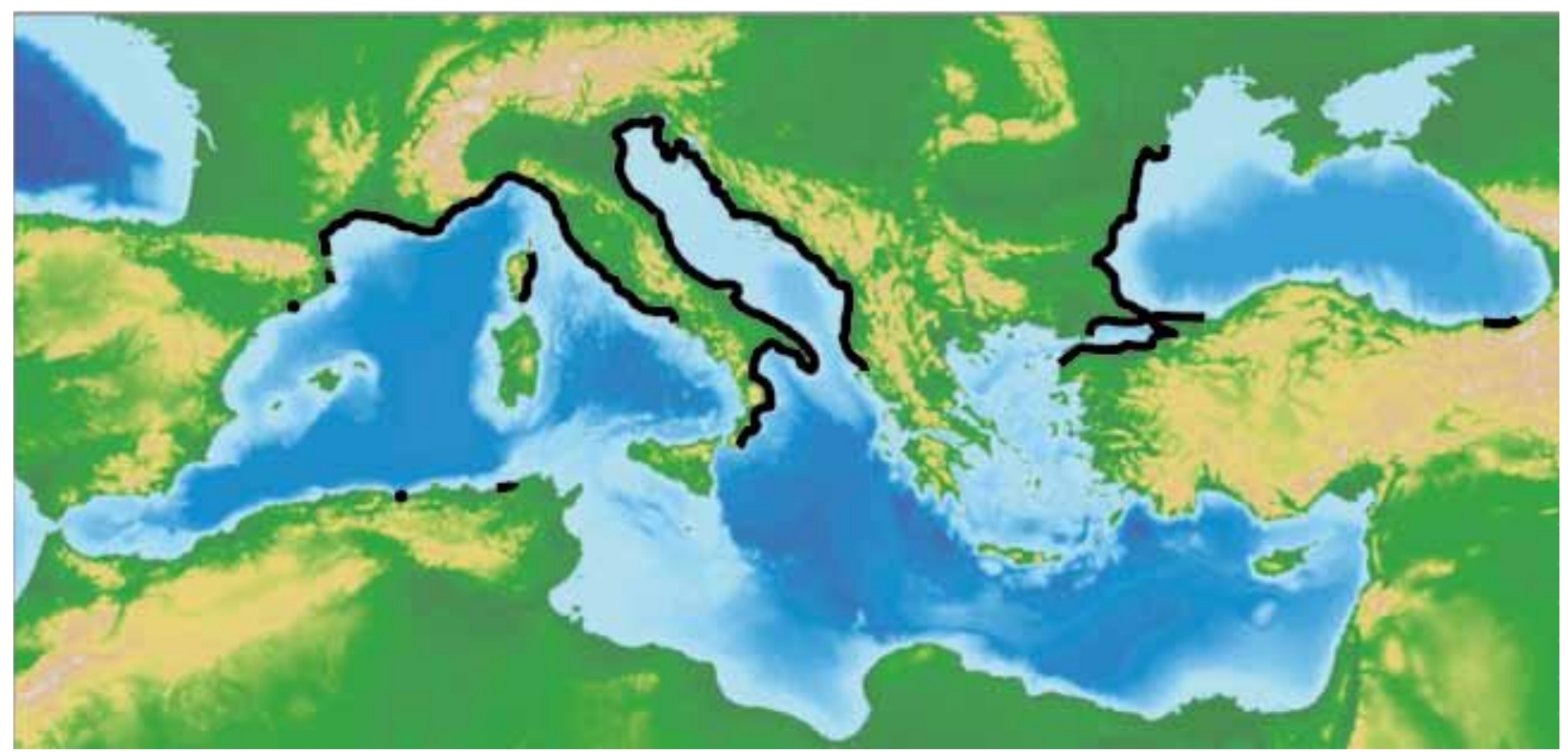

Figura 2. Àrea de distribució d'Stachys maritima.

Taula 1. Avaluacions prèvies disponibles del risc d'extinció d'Stachys maritima segons els criteris de la UICN (2001).

\begin{tabular}{|lll|}
\hline Àmbit & Categoria i criteris & Font \\
\hline Mundial & NE (no avaluada) & \\
Espanya & CR: B1ab(i,ii,iii,iv,v)+2(i,ii,iii,iv,v); & Molero et al. (2007) \\
& C1+2a(ii) & \\
Catalunya & EN Alc $+4 \mathrm{c} ; \mathrm{B} 1 \mathrm{ab}(\mathrm{i}, \mathrm{ii}, \mathrm{iii}) \mathrm{c}(\mathrm{iv})$ & Sáez et al. $(2010)$ \\
& $+2 \mathrm{ab}(\mathrm{i}, \mathrm{ii}, \mathrm{iii}) \mathrm{c}(\mathrm{iv})+\mathrm{C} 2 \mathrm{~b}$ & \\
\hline
\end{tabular}

A l'entorn de la ciutat de Barcelona, d'on s'ha documentat des de molt antic la seva presència ("Portal de Mar", a l'Herbari Salvador, cf. Ibáñez, 2006) i on havia arribat a ser freqüent, des de Can Tunis fins al Besòs (Barriocanal \& Blanché, 2002) (Fig. 3), no ha pogut ser retrobada en cap localitat i s'ha de donar, segons els coneixements actuals, com a extingida al Barcelonès. Fora del nucli del Prat de Llobregat, la resta de poblacions actualment conegudes d'Stachys maritima es distribueixen al llarg d'uns $40 \mathrm{~km}$ de franja costanera empordanesa (comarques de l'Alt i el Baix Empordà). Tot i que la massiva transformació del litoral empordanès (Fig. 4) ha suposat quasi amb total seguretat una important regressió de l'espècie, aquesta encara és present a la majoria de poblacions recol-lectades durant el darrer segle (Fig. 5). Totes les poblacions conegudes han estat objecte d'un seguiment conti- nuat, que va iniciar-se fa 10 anys (2001-2010), els resultats del qual poden oferir una sèrie de dades que permeten l'anàlisi de l'estat de conservació i de la biologia de l'espècie amb una perspectiva més àmplia $\mathrm{i}$ documentada.

D'altra banda, durant els primers anys de seguiment (2002-2003), es va dur a terme un estudi de diversitat genètica de totes les poblacions conegudes d'Stachys maritima en aquells moments (LópezPujol et al., 2003), que va revelar uns baixos nivells de variació isoenzimàtica i una certa estructuració de la diversitat, que van atribuir-se a la fragmentació dels seus hàbitats naturals $i$ el consegüent aïllament genètic entre poblacions. Actualment, aquest estudi es pot considerar incomplet, puix que els nuclis descoberts amb posterioritat (com ara el del Baix Llobregat o diversos grups d'individus empordanesos) no hi eren inclosos. 

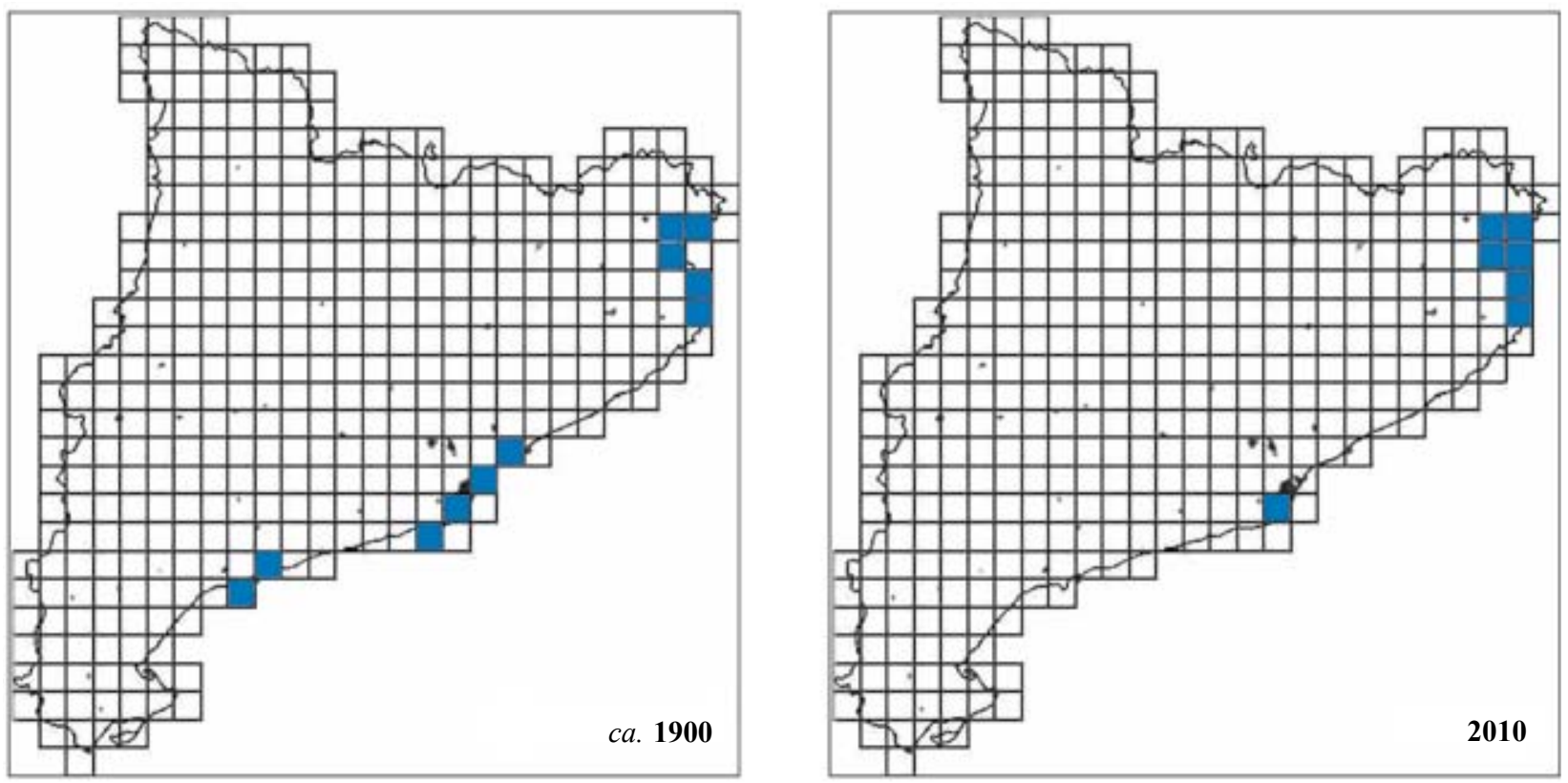

Figura 3. Comparativa de l'àrea de distribució d'Stachys maritima (detallada mitjançant quadrats UTM $10 \mathrm{x} 10 \mathrm{~km}$ ) a principis del segle passat (segons dades recopilades a Barriocanal \& Blanché, 2002) i l'any 2010.

En aquest treball, presentem una recopilació de la informació actualment existent sobre Stachys maritima, reunint les dades acumulades pels autors durant aquests anys i de la bibliografia que disposem, dels seguiments demogràfics, dels estudis de diversitat genètica realitzats amb posterioritat i de les dades sobre biologia de l'espècie. Aquest conjunt d'informacions permeten establir una base científica per a la redacció del preceptiu pla de recuperació de l'espècie, requerit per l'aplicació del
Decret 172/2008, de creació del Catàleg de Flora Amenaçada de Catalunya (DOGC, 2008).

\section{MATERIAL I MÈTODES}

\section{Demografia i censos poblacionals}

Des de l'any 2001 i fins al 2010, s'ha procedit al seguiment demogràfic per recompte del nombre total d'individus de tots els nuclis coneguts
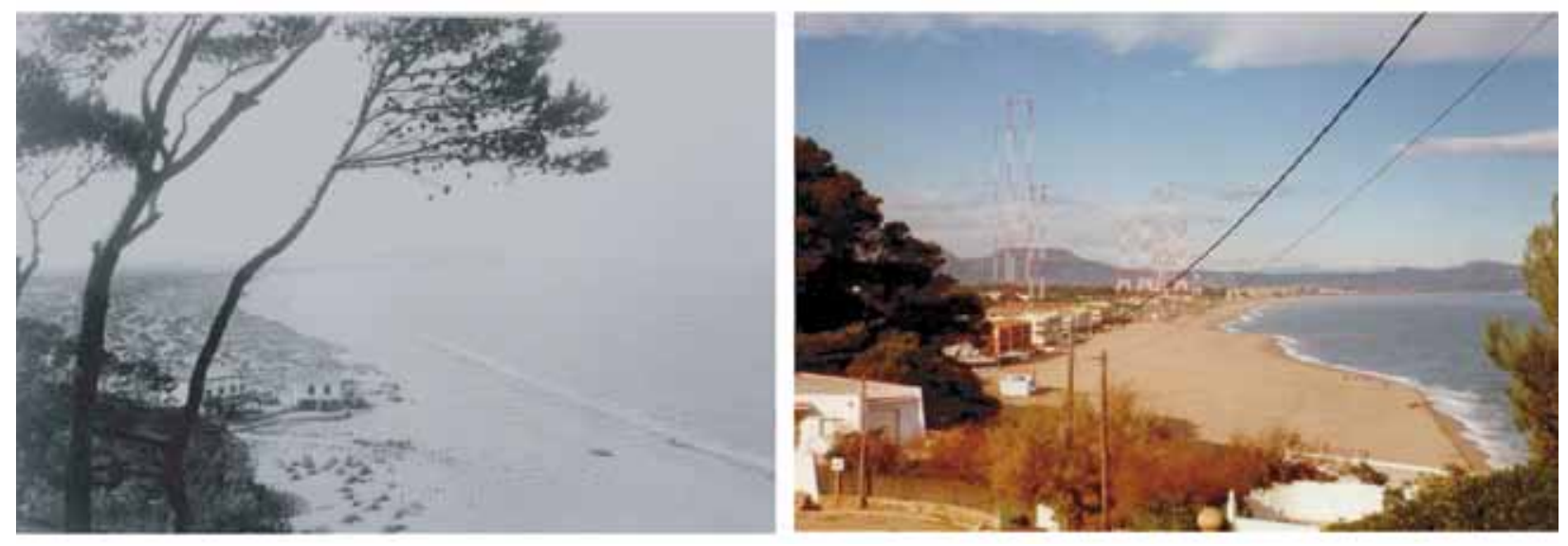

Figura 4. Platja de Pals (Baix Empordà) a l'any 1910 (a l'esquerra) i a mitjans de la dècada present (a la dreta). [Fotografies: esquerra, arxiu personal de C. Blanché; dreta: C. Blanché]. 
d'Stachys maritima a Catalunya (Fig. 5). Les visites s'han dut a terme entre els mesos de juny i agost (màxima visibilitat de les inflorescències) i s'han considerat tots els individus visibles en el moment de la visita, independentment de la seva mida i estat fenològic. Addicionalment, es va procedir, durant els anys de seguiment, a l'exploració d'àrees amb hàbitat potencial per aquesta espècie, cosa que ha permès la localització de nous nuclis, que es van afegir a l'estudi a partir de l'any del seu descobriment. Tots els nuclis poblacionals s'han georeferenciat amb l'ajuda d'un receptor GPSmap 60Cx de Garmin.

\section{Diversitat genètica i seguiment genètic}

Per a complementar l'estudi de variabilitat genètica i estructura poblacional dut a terme per López-Pujol et al. (2003), durant l'any 2008 es van mostrejar aquelles poblacions d'Stachys maritima que no havien estat incloses en l'estudi anterior, i que es corresponien amb les noves troballes durant el període 2004-2008: alguns nuclis naturals de l'Empordà, el nucli del Prat de Llobregat i els nuclis considerats "artificials" (Taules 2, 3 i 4, on consten els resultats tant de l'estudi anterior com els de l'actualització present, de manera que constitueix l'expressió de l'estat actual total de coneixement sobre diversitat genètica de l'espècie). Hom pot considerar aquests estudis com a part del seguiment genètic (genetic monitoring), dut a terme en paral-lel al seguiment demogràfic esmentat més amunt: forneixen informació actualitzada que permet la correcció de les mesures de gestió en un context de conservació adaptativa.

Excepte per als nuclis més petits, on es van collir mostres de tots els individus disponibles, el mostratge es va dur a terme mitjançant un transsecte lineal, prenent mostres cada 50-100 cm per tal d'evitar la recol-lecció de ramets del mateix genet. Les mostres collides, seguint tècniques no destructives per als individus, van consistir en fragments de fulles basals, i es van conservar a $4{ }^{\circ} \mathrm{C}$ fins al moment de l'extracció, un dia després de la recol·lecció.

La diversitat genètica es va avaluar utilitzant els mètodes estàndard per a electroforesi d'isoenzims (Soltis et al., 1983; Kephart, 1990). Emprant gels de midó a 1'11\%, es van resoldre 13 enzims en 4 sistemes de tampons, obtenint 20 loci interpretables: Aat-1, Aco-1, Aco-3, Acp-2, Adh-1, Dia-1, Idh-2, Idh-3, Mdh-1, Mdh-2, 6Pgd-1, 6Pgd-2, Pgi-1,
Pgi-2, Pgm-1, Pgm-2, Skd, Sod-1, Tpi-1 i Tpi-2. L'aconitat hidratasa (ACO, EC 4.2.1.3), l'àcid fosfatasa (ACP, EC 3.1.3.2), la malat deshidrogenasa (MDH, EC 1.1.1.37), la fosfoglucoisomerasa (PGI, EC 5.3.1.9), la fosfoglucomutasa (PGM, EC 5.4.2.2) i la superòxid dismutasa (SOD, EC 1.15.1.1) es van resoldre satisfactòriament amb el tampó d'histidinacitrat a pH 5,7 (Jefferies \& Gottlieb, 1982); l'alcohol deshidrogenasa (ADH, EC 1.1.1.1), la fosfogluconat deshidrogenasa (6PGD, EC 1.1.1.44) i la xiquimat deshidrogenasa (SKD, EC 1.1.1.25) es van resoldre amb el tampó de morfolina-citrat a pH 6,1 (Odrzykoski \& Gottlieb, 1984); i l'aspartat aminotranferasa (AAT, EC 2.6.1.1), la diaforasa (DIA, EC 1.6.99.-) i la triosafosfat isomerasa (TPI, EC 5.3.1.1) ho van fer amb el tampó de tris-citrat/ liti-borat a pH 8,2 (Scandalios, 1969). Només la isocitrat deshidrogenasa (IDH, EC 1.1.1.42) es va obtenir amb el tampó d'histidina pH 7,0 (Wendel \& Weeden, 1989). Els procediments de tinció per a tots els enzims seguiren el mètode descrit per Vallejos (1983), Shields et al. (1983) i Wendel \& Weeden (1989), amb petites modificacions.

Els loci es van numerar consecutivament i els al·lels de cada locus es van designar alfabèticament, començant pel més anòdic. La interpretació dels patrons de bandes es va realitzar segons els principis estàndard (Gottlieb, 1982; Kephart, 1990) i es van computar els següents paràmetres estadístics: $P$, el percentatge de loci polimòrfics (considerant que un locus és polimòrfic quan la freqüència de l'al·lel més comú és inferior a 0,95$) ; A$, el nombre mitjà d'al·lels per locus; $H_{\mathrm{o}}$, l'heterozigosi observada i $H_{\mathrm{e}}$, l'heterozigosi esperada. També es calculà l'índex de fixació $(F)$ mitjà per a tots els loci polimòrfics i s'analitzà l'estructura de poblacions usant els estadístics$F$ de Wright $(1951,1965)$. El càlcul de tots els paràmetres es va dur a terme amb el programa BIOSYS-1 (Swofford \& Selander, 1989).

\section{RESULTATS I DISCUSSIÓ}

\section{Demografia i censos poblacionals}

La recerca del tàxon pel litoral de Catalunya durant el període 2001-2010 ha donat lloc a la constatació de la seva més que probable desaparició en diversos indrets on havia estat documentat o, com a mínim, citat: no ha estat possible retrobar-lo al Tarragonès, 


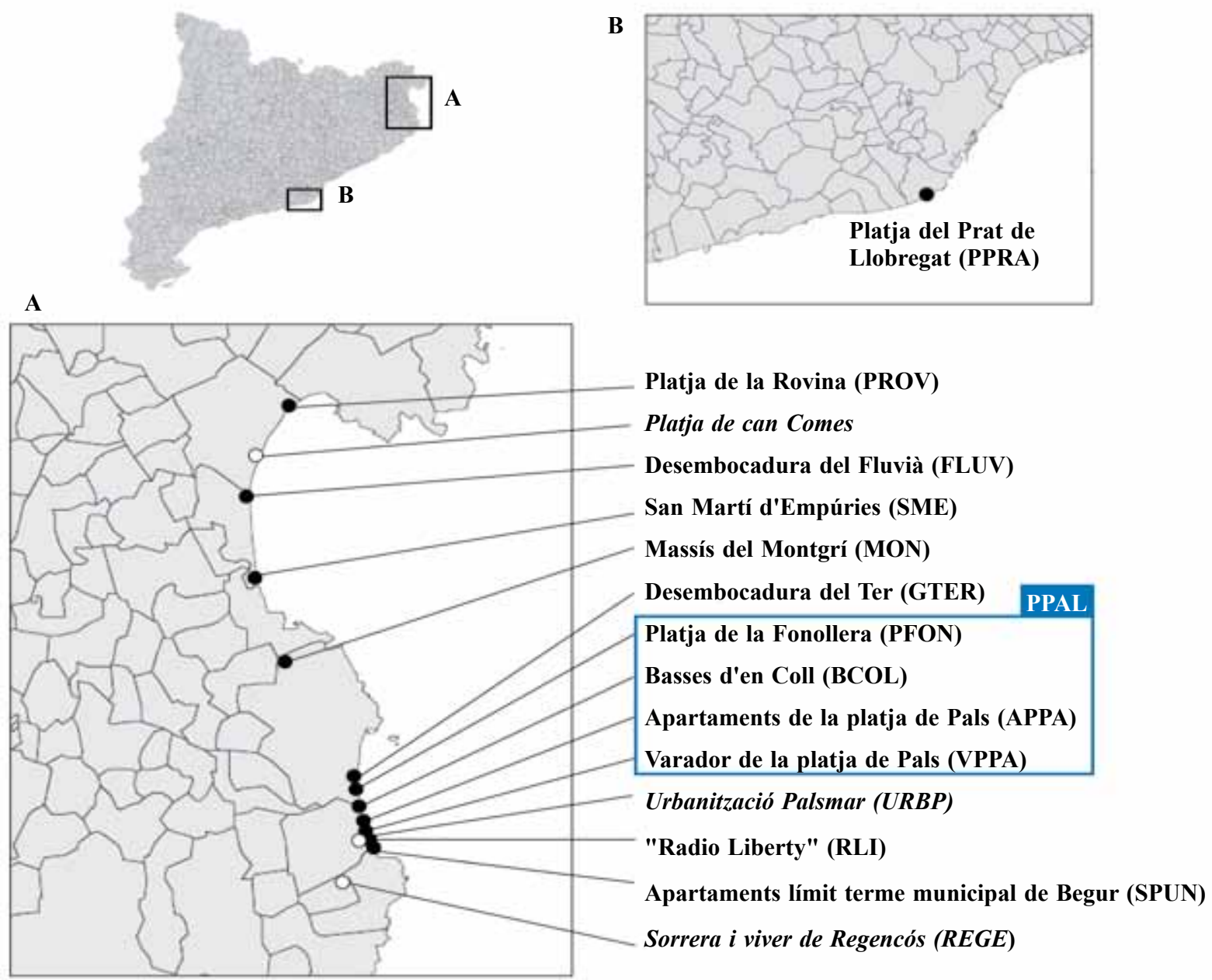

Figura 5. Localització de les poblacions actuals d'Stachys maritima. Els cercles blancs (que corresponen als noms en cursiva) indiquen poblacions no incloses a la Taula 5. Entre parèntesi s'inclouen els codis poblacionals. PPAL (en blau) és el codi que s'empra en l'anàlisi de la diversitat genètica per a designar el conjunt de nuclis poblacionals de la platja de Pals (vegeu Taula 2).

al Garraf ni al Barcelonès. Els nuclis romanents es localitzen al delta del Llobregat (una única població) i a les comarques de l'Alt i el Baix Empordà (la resta de poblacions). En un recorregut en sentit nord-sud, el àmbits geogràfics d'on es coneix Stachys maritima es detallen a continuació, amb indicació de llurs característiques (vegeu també el mapa de la Fig. 5):

Platja de la Rovina (badia de Roses, Alt Empordà, 31TEG17; Fig. 6A).

Platja de sorra d'1,7 quilòmetres, bona part de la qual es troba inserida dins els límits del Parc Natural dels Aiguamolls de l'Empordà. Es troba entre dues grans marines (Santa Margarida i Empuriabrava) que es van construir a finals dels anys 60 . El nucli on $\mathrm{s}$ 'ha detectat l'espècie es troba fora dels límits del Parc Natural (sector del nord de la platja) darrere del sistema dunar litoral. El sistema dunar no és gaire alt $i$ està molt afectat pel vent de tramuntana i pels temporals de llevant que mouen les sorres cap a l'interior. La platja és concorreguda els mesos d'estiu per banyistes i practicants d'esports de vent. A la visita de 2010 s'ha detectat una important expansió de l'al-lòctona Oenothera biennis L. (Fig. 7A). En anys anteriors s'havia detectat una presència significativa d'una espècie autòctona però d'hàbitat generalista, Ononis natrix L. (Fig. 7B), tot i que enguany no l'hem pogut observar.

Desembocadura del Fluvià (badia de Roses, Alt Empordà, 31TEG07; Fig. 6B).

Gola i platges adjacents de sorra, conegudes com Platja de la Gola al sud i Platja de Can Comes al nord. Tot aquest indret es troba dins el Parc Natural 
Taula 2. Poblacions d'Stachys maritima mostrejades per a l'estudi de la diversitat genètica.

\begin{tabular}{|c|c|c|c|}
\hline & Codi & $\begin{array}{c}\text { Any de } \\
\text { mostratge }\end{array}$ & $\begin{array}{c}\text { Mida } \\
\text { mostral }\end{array}$ \\
\hline \multicolumn{4}{|c|}{ POBLACIONS NATURALS } \\
\hline Platja Rovina & PROV & 2002 & 24 \\
\hline $\begin{array}{l}\text { Desembocadura } \\
\text { del Fluvià }\end{array}$ & FLUV & 2008 & 8 \\
\hline \multicolumn{4}{|l|}{ Sant Martí d'Empúries } \\
\hline Nucli 1 & SME1 & 2003 & 1 \\
\hline Nucli 2 & SME2 & 2008 & 14 \\
\hline \multicolumn{4}{|l|}{ Massís del Montgrí } \\
\hline Nucli 1 & MON1 & 2008 & 3 \\
\hline \multicolumn{4}{|l|}{ Desembocadura } \\
\hline $\begin{array}{l}\text { Platja de Pals }{ }^{1} \\
\text { Apartaments }\end{array}$ & \multicolumn{2}{|c|}{ Apartaments } & 71 \\
\hline Platja de Begur & SPUN & 2003 & 21 \\
\hline El Prat de Llobregat & PPRA & 2008 & 11 \\
\hline \multicolumn{4}{|c|}{ POBLACIONS ARTIFICIALS } \\
\hline Viver de Regencós & REGE & 2008 & 15 \\
\hline Sorral del Montgrí & MON2 & 2008 & 35 \\
\hline Urbanització Palsmar & URBP & 2008 & 7 \\
\hline \multicolumn{4}{|c|}{$\begin{array}{l}{ }^{1} \text { Al'estudi genètic, la població PPAL (Platja de Pals) inclou } \\
\text { els següents nuclis de seguiment demogràfic de la Taula 5: } \\
\text { PFON (Platja Fonollera), BCOL (Basses d'en Coll), APPA } \\
\text { (Apartaments platja de Pals) i Varador Pals (VPPA). }\end{array}$} \\
\hline
\end{tabular}

dels Aiguamolls de l'Empordà. Els nuclis s'han localitzat a dunes consolidades de l'interior (100-150 metres del litoral), a la part elevada de petits turons. Tot i que es tracta d'una zona antigament freqüentada per vehicles, darrerament s'hi ha restringit l'accés i el Parc Natural ha ordenat el trànsit de vianants, de banyistes i de practicants d'esports de platja durant els mesos d'estiu. A les darreres visites efectuades a la població s'ha detectat una presència important de les invasores Arundo donax L. (Fig. 7C). i Xanthium strumarium L. subsp. italicum (Moretti) D. Löve.

Sant Martí d'Empúries (badia de Roses, Alt Empordà, 31TEG06; Fig. 6C).

Sector de la desembocadura del riu Vell, que prové del rec del Molí (rec d'irrigació corresponent al sistema de regadiu de la zona dels aiguamolls de l'Empordà). El nucli detectat recentment en aquest indret (nucli 2, Taula 5) és una acumulació de sorra d'origen desconegut. L'any 2009 la zona va ser objecte de treballs d'arranjament de la platja de la riera que van comportar el cobriment amb sorra de diversos grups d'individus. Es troba dins els límits del Parc Natural dels Aiguamolls de l'Empordà. En aquest sector hi ha cites històriques del $\mathrm{s}$. XIX de nuclis no retrobats $i$, anys enrere, es mantenia un nucli d'individus prop de la discoteca "Fata Morgana" (nucli 1, Taula 5), sota els efectes del trepig i, després, cobert de sorra i de materials de windsurf, $\mathrm{i}$ no retrobat des de 2003. També en aquesta població (al nucli 2) hem detectat una presència significativa de Xanthium strumarium subsp. italicum (Fig. 7D).

Massís del Montgrí (Baix Empordà, 31TEG16; Fig. 6D).

Es tracta d'un massís calcari amb presència de sorrals que corresponen a dunes fixades amb pins, fruit d'un projecte forestal de finals del s. XIX sobre la duna continental. Els nuclis poblacionals localitzats al massís es troben a una distància de gairebé dos quilòmetres del litoral. Aquesta població va ser detectada l'any 2004 arran d'una prospecció florística genèrica, no pas específica per a Stachys maritima, i es va fixar l'atenció sobre la possibilitat de trobar l'espècie en sorrals interiors (Barriocanal, 2005). L'indret és freqüentat per vehicles tot terreny (motos, quads, etc.), hi discorre un camí antic i s'hi fan abocaments de runa i de brossa incontrolats de manera reiterada, tot i la senyalització que ho prohibeix. La població consisteix de 4 nuclis separats a escassos metres els uns dels altres. Un d'aquests (nucli 2, Taula 5) és possiblement d'origen antròpic donat que està situat en un indret on hi ha importants moviments de sorra (Fig. 6E).

Desembocadura del Ter (badia de Pals, Baix Empordà, 31TEG15).

Sector que correspon a la gola del Ter i les platges adjacents (Platja de l'Estartit al nord i Platja de la Gola del Ter al sud), amb dunes altes a la banda sud. Concretament, la població es troba situada a la banda sud de la gola, al sector reredunar. És exposada als efectes de les llevantades (moviments de sorra) i a la freqüentació per banyistes i practicants d'esports de platja.

Platja de la Fonollera (badia de Pals, Baix Empordà, 31TEG15).

Tram de platja localitzat a continuació de la platja de la Gola del Ter, d'un quilòmetre i situat davant del càmping "El Delfín Verde". Limita al sud amb 
Taula 3. Freqüències al·lèliques per a 20 loci als nuclis estudiats d'Stachys maritima.

\begin{tabular}{|c|c|c|c|c|c|c|c|c|c|c|c|c|c|}
\hline \multirow[b]{2}{*}{ Locus } & \multirow[b]{2}{*}{ Al·lel } & \multirow[b]{2}{*}{ PROV } & \multicolumn{6}{|c|}{ Pobl. naturals } & \multicolumn{5}{|c|}{ Pobl. artificials } \\
\hline & & & FLUV & SME1 & SME2 & GTER & MON1 & PPAL & SPUN & PPRA & REGE & MON2 & URBP \\
\hline Aat-1 & $a$ & 1,000 & 1,000 & 1,000 & 1,000 & 1,000 & 1,000 & 1,000 & 1,000 & 1,000 & 1,000 & 1,000 & 1,000 \\
\hline Aco-1 & $\begin{array}{l}a \\
b\end{array}$ & $\begin{array}{l}1,000 \\
0,000\end{array}$ & $\begin{array}{l}1,000 \\
0,000\end{array}$ & $\begin{array}{l}1,000 \\
0,000\end{array}$ & $\begin{array}{l}1,000 \\
0,000\end{array}$ & $\begin{array}{l}0,929 \\
0,071\end{array}$ & $\begin{array}{l}1,000 \\
0,000\end{array}$ & $\begin{array}{l}0,824 \\
0,176\end{array}$ & $\begin{array}{l}1,000 \\
0,000\end{array}$ & $\begin{array}{l}1,000 \\
0,000\end{array}$ & $\begin{array}{l}1,000 \\
0,000\end{array}$ & $\begin{array}{l}1,000 \\
0,000\end{array}$ & $\begin{array}{l}1,000 \\
0,000\end{array}$ \\
\hline Aco-3 & $a$ & 1,000 & 1,000 & 1,000 & 1,000 & 1,000 & 1,000 & 1,000 & 1,000 & 1,000 & 1,000 & 1,000 & 1,000 \\
\hline Acp-2 & $a$ & 1,000 & 1,000 & 1,000 & 1,000 & 1,000 & 1,000 & 1,000 & 1,000 & 1,000 & 1,000 & 1,000 & 1,000 \\
\hline Adh-1 & $a$ & 1,000 & 1,000 & 1,000 & 1,000 & 1,000 & 1,000 & 1,000 & 1,000 & 1,000 & 1,000 & 1,000 & 1,000 \\
\hline Dia-1 & $a$ & 1,000 & 1,000 & 1,000 & 1,000 & 1,000 & 1,000 & 1,000 & 1,000 & 1,000 & 1,000 & 1,000 & 1,000 \\
\hline$I d h-2$ & $\begin{array}{l}a \\
b\end{array}$ & $\begin{array}{l}1,000 \\
0,000\end{array}$ & $\begin{array}{l}0,688 \\
0,313\end{array}$ & $\begin{array}{l}0,000 \\
1,000\end{array}$ & $\begin{array}{l}1,000 \\
0,000\end{array}$ & $\begin{array}{l}1,000 \\
0,000\end{array}$ & $\begin{array}{l}1,000 \\
0,000\end{array}$ & $\begin{array}{l}1,000 \\
0,000\end{array}$ & $\begin{array}{l}1,000 \\
0,000\end{array}$ & $\begin{array}{l}1,000 \\
0,000\end{array}$ & $\begin{array}{l}1,000 \\
0,000\end{array}$ & $\begin{array}{l}1,000 \\
0,000\end{array}$ & $\begin{array}{l}1,000 \\
0,000\end{array}$ \\
\hline$I d h-3$ & $a$ & 1,000 & 1,000 & 1,000 & 1,000 & 1,000 & 1,000 & 1,000 & 1,000 & 1,000 & 1,000 & 1,000 & 1,000 \\
\hline$M d h-1$ & $a$ & 1,000 & 1,000 & 1,000 & 1,000 & 1,000 & 1,000 & 1,000 & 1,000 & 1,000 & 1,000 & 1,000 & 1,000 \\
\hline$M d h-2$ & $\begin{array}{l}a \\
b\end{array}$ & $\begin{array}{l}0,750 \\
0,250\end{array}$ & $\begin{array}{l}1,000 \\
0,000\end{array}$ & $\begin{array}{l}1,000 \\
0,000\end{array}$ & $\begin{array}{l}1,000 \\
0,000\end{array}$ & $\begin{array}{l}1,000 \\
0,000\end{array}$ & $\begin{array}{l}1,000 \\
0,000\end{array}$ & $\begin{array}{l}0,986 \\
0,014\end{array}$ & $\begin{array}{l}1,000 \\
0,000\end{array}$ & $\begin{array}{l}1,000 \\
0,000\end{array}$ & $\begin{array}{l}1,000 \\
0,000\end{array}$ & $\begin{array}{l}1,000 \\
0,000\end{array}$ & $\begin{array}{l}1,000 \\
0,000\end{array}$ \\
\hline $6 P g d-1$ & $a$ & 1,000 & 1,000 & 1,000 & 1,000 & 1,000 & 1,000 & 1,000 & 1,000 & 1,000 & 1,000 & 1,000 & 1,000 \\
\hline $6 P g d-2$ & $\begin{array}{l}a \\
b\end{array}$ & $\begin{array}{l}1,000 \\
0,000\end{array}$ & $\begin{array}{l}1,000 \\
0,000\end{array}$ & $\begin{array}{l}1,000 \\
0,000\end{array}$ & $\begin{array}{l}0,000 \\
1,000\end{array}$ & $\begin{array}{l}0,571 \\
0,429\end{array}$ & $\begin{array}{l}1,000 \\
0,000\end{array}$ & $\begin{array}{l}0,298 \\
0,702\end{array}$ & $\begin{array}{l}0,132 \\
0,868\end{array}$ & $\begin{array}{l}1,000 \\
0,000\end{array}$ & $\begin{array}{l}0,125 \\
0,875\end{array}$ & $\begin{array}{l}0,697 \\
0,303\end{array}$ & $\begin{array}{l}0,000 \\
1,000\end{array}$ \\
\hline Pgi-1 & $a$ & 1,000 & 1,000 & 1,000 & 1,000 & 1,000 & 1,000 & 1,000 & 1,000 & 1,000 & 1,000 & 1,000 & 1,000 \\
\hline Pgi-2 & $a$ & 1,000 & 1,000 & 1,000 & 1,000 & 1,000 & 1,000 & 1,000 & 1,000 & 1,000 & 1,000 & 1,000 & 1,000 \\
\hline Pgm-1 & $a$ & 1,000 & 1,000 & 1,000 & 1,000 & 1,000 & 1,000 & 1,000 & 1,000 & 1,000 & 1,000 & 1,000 & 1,000 \\
\hline Pgm-2 & $a$ & 1,000 & 1,000 & 1,000 & 1,000 & 1,000 & 1,000 & 1,000 & 1,000 & 1,000 & 1,000 & 1,000 & 1,000 \\
\hline Skd & $a$ & 1,000 & 1,000 & 1,000 & 1,000 & 1,000 & 1,000 & 1,000 & 1,000 & 1,000 & 1,000 & 1,000 & 1,000 \\
\hline Sod-1 & $a$ & 1,000 & 1,000 & 1,000 & 1,000 & 1,000 & 1,000 & 1,000 & 1,000 & 1,000 & 1,000 & 1,000 & 1,000 \\
\hline Tpi-1 & $a$ & 1,000 & 1,000 & 1,000 & 1,000 & 1,000 & 1,000 & 1,000 & 1,000 & 1,000 & 1,000 & 1,000 & 1,000 \\
\hline Tpi-2 & $a$ & 1,000 & 1,000 & 1,000 & 1,000 & 1,000 & 1,000 & 1,000 & 1,000 & 1,000 & 1,000 & 1,000 & 1,000 \\
\hline
\end{tabular}

la gola del Daró o rec del Molí. La població es troba disseminada al llarg de tota la platja, al sector reredunar tot i que alguns peus es localitzen a zones d'aparcament de cotxes. Aquest sector pertany a l'EIN Aiguamolls del Baix Empordà, actualment a l'interior del Parc Natural Montgrí-Medes-Baix $\mathrm{Ter}^{1}$. A l'estiu és freqüentada per banyistes i practicants d'esports de platja.
Basses d'en Coll (badia de Pals, Baix Empordà, 31TEG15).

Espai humit corresponent a l'EIN dels Aiguamolls del Baix Empordà i ara a la Reserva Natural Parcial dels Aiguamolls del Baix Ter dins el Parc Natural del Montgrí-Medes-Baix Ter. L'espai inclou la part de la gola del Daró fins als primers apartaments de la platja de Pals. El sector té dunes altes i ben

\footnotetext{
${ }^{1}$ Llei 15/2010, del 28 de maig, de declaració del Parc Natural del Montgrí, de les Illes Medes i el Baix Ter, de dues reserves naturals parcials i una reserva natural integral. Parlament de Catalunya.
} 
Taula 4. Resum de la variació genètica per a 20 loci als nuclis d'Stachys maritima. P: percentatge de loci polimòrfics; $A$ : nombre mitjà d'al·lels per locus; $H_{\mathrm{o}}$ : heterozigosi observada; $H_{\mathrm{e}}$ : heterozigosi esperada. Error estàndard entre parèntesi.

\begin{tabular}{|c|c|c|c|c|}
\hline Població & $P$ & $\boldsymbol{A}$ & $H_{0}$ & $\boldsymbol{H}_{\mathrm{e}}$ \\
\hline \multicolumn{5}{|l|}{ POBL. NATURALS } \\
\hline PROV & 5,0 & 1,0 & $0,008(0,008)$ & $0,019(0,019)$ \\
\hline FLU & 5,0 & 1,0 & $0,006(0,006)$ & $0,023(0,023)$ \\
\hline SME1 & 0,0 & 1,0 & $0,000(0,000)$ & $0,000(0,000)$ \\
\hline SME2 & 0,0 & 1,0 & $0,000(0,000)$ & $0,000(0,000)$ \\
\hline MON1 & 0,0 & 1,0 & $0,000(0,000)$ & $0,000(0,000)$ \\
\hline GTER & 10,0 & 1,1 & $0,007(0,007)$ & $0,034(0,027)$ \\
\hline PPAL & 10,0 & 1,1 & $0,016(0,010)$ & $0,037(0,025)$ \\
\hline SPUN & 5,0 & 1,0 & $0,013(0,013)$ & $0,012(0,012)$ \\
\hline PPRA $^{1}$ & 0,0 & 1,0 & $0,000(0,000)$ & $0,000(0,000)$ \\
\hline PPRA $^{2}$ & 4,8 & 1,0 & $0,000(0,000)$ & $0,015(0,015)$ \\
\hline Mitjana & 3,9 & 1,0 & 0,006 & 0,014 \\
\hline Desviació estàndard & 4,2 & 0,0 & 0,006 & 0,015 \\
\hline \multicolumn{5}{|l|}{ POBL. ARTIFICIALS } \\
\hline MON2 & 5,0 & 1,0 & $0,012(0,012)$ & $0,021(0,021)$ \\
\hline URBP & 0,0 & 1,0 & $0,000(0,000)$ & $0,000(0,000)$ \\
\hline REGE & 5,0 & 1,0 & $0,000(0,000)$ & $0,012(0,012)$ \\
\hline Mitjana & 3,3 & 1 & 0,004 & 0,011 \\
\hline Desviació estàndard & 2,9 & 0 & 0,007 & 0,011 \\
\hline Mitjana S. maritima & 3,8 & 1,0 & 0,005 & 0,013 \\
\hline Desviació estàndard & 3,8 & 0,0 & 0,006 & 0,014 \\
\hline \multicolumn{5}{|c|}{$\begin{array}{l}{ }^{1} \text { Sense tenir en consideració el locus Aco-2. El locus Aco-2 només s'ha pogut resoldre de forma òptima per a la població } \\
\text { PPRA, i per tant no s'ha considerat per als càlculs dels paràmetres genètics per al global de l'espècie (però sí per a l'anàlisi } \\
\text { del cas particular de la població PPRA). }\end{array}$} \\
\hline
\end{tabular}

desenvolupades amb un ampli espai reredunar, on es localitza Stachys maritima. Aquest espai és ocupat a l'estiu per banyistes, hi discorre un corriol freqüentat i és inundat temporalment de manera ocasional. En els darrers anys s'hi ha censat espècies al-lòctones en expansió (Cyperus sp., Amorpha fruticosa L., Oenothera biennis, etc.). Alguns individus es troben molt a prop de l'aparcament d'accés i han estat trepitjats en diverses ocasions; a l'actualitat s'hi ha instal-lat obstacles que n'impedeixen l'accés directe com ara pedres i estaques amb cordes.

Apartaments de la platja de Pals (badia de Pals, Baix Empordà, 31TEG14).

Espai de platja de 0,5 quilòmetres davant d'uns apartaments situats a primera línia de mar. Dunes altes $\mathrm{i}$ ben desenvolupades amb espai reredunar abans de la presència d'un passeig marítim i els blocs d'apartaments. Tot i els cordatges que hi veten l'accés, és freqüentat per passavolants, gossos i curiosos. La zona és afectada per l'expansió de Carpobrotus spp., procedent de jardins propers (Fig. 7E). Des de 2006 s'ha procedit al recanvi de les espècies plantades en apartaments propers amb alternatives no invasores, a instàncies dels gestors de l'EIN Basses d'en Coll.

Varador de la platja de Pals (badia de Pals, Baix Empordà, 31TEG14).

Petit espai ( $c a .100$ metres de longitud) molt significatiu: ha estat l'indret on més peus de l'espècie s'han detectat durant molts anys, després d'un episodi de reclutament posterior a l'aplanament parcial de la rereduna per l'arranjament de l'aparcament de 
Taula 5. Evolució de la mida de les poblacions d'Stachys maritima conegudes a Catalunya entre els anys 2001 i 2010.

\begin{tabular}{|c|c|c|c|c|c|c|c|c|c|c|c|}
\hline Sector & Codi & 2001 & 2002 & 2003 & 2004 & 2005 & 2006 & 2007 & 2008 & 2009 & 2010 \\
\hline Platja Rovina & PROV & 11 & 92 & - & 46 & 104 & 109 & - & 61 & 338 & $338^{1}$ \\
\hline Desembocadura del Fluvià & FLUV & 8 & 0 & 0 & 6 & 5 & - & 3 & 8 & 7 & 9 \\
\hline \multicolumn{12}{|l|}{ Sant Martí d'Empúries } \\
\hline Nucli 1 & SME1 & 8 & 0 & 1 & 0 & 0 & 0 & 0 & 0 & 0 & 0 \\
\hline Nucli 2 & SME2 & & & & & & 1 & 4 & 20 & 6 & 4 \\
\hline \multicolumn{12}{|l|}{ Massís del Montgrí } \\
\hline Nucli 1 & MON1 & & & & 23 & 67 & - & 90 & 3 & 9 & 0 \\
\hline Nucli 3 & MON3 & & & & & & & & & 32 & 21 \\
\hline Nucli 4 & MON4 & & & & & & & & & 11 & 3 \\
\hline Desembocadura del Ter & GTER & 9 & 9 & - & 0 & 12 & - & 7 & 20 & - & 0 \\
\hline Platja Fonollera & PFON & 17 & 19 & - & 0 & 2 & - & 2 & 26 & 2 & 0 \\
\hline Basses d'en Coll & BCOL & 22 & 40 & 59 & 7 & 2 & 1 & 30 & 10 & 0 & 3 \\
\hline Apartaments platja de Pals & APPA & 4 & - & 59 & 17 & & 12 & 10 & 6 & 1 & 0 \\
\hline Varador Pals & VPPA & 102 & 110 & 188 & 71 & 77 & - & 50 & 25 & 10 & 27 \\
\hline \multicolumn{12}{|l|}{ "Radio Liberty"3 } \\
\hline Exterior del recinte & RLI1 & 0 & 0 & 0 & 2 & 2 & 1 & 17 & 11 & - & - \\
\hline Interior del recinte & RLI2 & & & & & & & & 1523 & 821 & 12 \\
\hline Apartaments platja de Begur & SPUN & 11 & - & 25 & 6 & 12 & - & 20 & 12 & - & 0 \\
\hline El Prat de Llobregat & PPRA & & & & & & 1 & - & 11 & 11 & 1 \\
\hline
\end{tabular}

remolcs, on va existir un petit varador per a esports nàutics (Fig. 7F). Des de l'any 2003 es va limitar l'accés de vehicles a la zona. Dunes molt elevades al primer cordó i espai reredunar ampli.

"Radio Liberty" (badia de Pals, Baix Empordà, 31TEG14; Fig. 6F).

Espai corresponent a les antigues instal-lacions de l'emissora "Radio Liberty". Inicialment, es va fer el seguiment a la zona litoral atès que el recinte de les instal-lacions era tancat i no s'hi podia accedir. Un cop es van enderrocar les antenes (2006) es va fer el seguiment al seu interior. El front litoral és d'1,4 quilòmetres i el recinte de les instal-lacions ocupa 38 hectàrees de les que aproximadament 15 corresponen a sorrals. L'any 2006 hi van ser introduïts individus provinents de la sorrera de Regencós (vegeu més avall).
Apartaments límit terme municipal de Begur (badia de Pals, Baix Empordà, 31TEG14; Fig. 6G).

Petit espai ( $c a .350$ metres) davant d'uns blocs d'apartaments al sector més meridional de la platja de Pals (Sa Punta). Davant els blocs existeixen unes petites dunes de poca alçada on $s$ 'ha registrat la presència d'Stachys maritima. Zona molt freqüentada a l'estiu pel pas de banyistes i dels propietaris dels apartaments.

Platja del Prat de Llobregat (Baix Llobregat, 31TDF27; Fig. 8).

Situat al costat de la zona de l'aeroport de Barcelona, el nucli poblacional conegut a l'actualitat correspon a una zona on es va dur a terme una acció d'eliminació de vegetació per afavorir zones obertes per a fauna dunar. La zona de platja on viu, al costat del passeig marítim, té ordenat l'accés a través de passeres i és objecte de diverses mesures 
de seguiment, d'eradicació d'invasores (Oenothera biennis) i de protecció i vigilància per part del Consorci del Delta del Llobregat. En els darrers anys s'ha produit una expansió important de l'invasora Ambrosia artemisiifolia $\mathrm{L}$.

A part d'aquests nuclis, que considerem naturals, l'any 2006 van aparèixer exemplars d'Stachys maritima a indrets d'acumulació artificial de sorres, on haurien arribat en el curs d'operacions de trasllat de substrats per a la construcció, procedents d'alguna platja propera, que haurien comportat també el trasllat conjunt de rizomes i/o de llavors. Es tracta, en concret, de centenars d'individus apareguts en una acumulació d'àrids a Regencós (Dacosta et al., 2008), dels quals 150 van ser translocats a la Platja de "Radio Liberty" (prop de la zona d'origen de les sorres; Fig. 6F) i 100 a un petit viver per a producció de llavors (Fig. 6H); totes dues accions coordinades des dels serveis territorials de Girona del DMAH. L'any 2008 es van detectar quinze individus situats en una illeta viària dins de l'entramat urbà de la urbanització Palsmar i uns 600 plançons trobats a un sorral prop de les poblacions del Montgrí (nucli 2; Fig. 6E). S'ha constatat la desaparició del nucli de Pals i una forta reducció del nucli del Montgrí (51 individus l'any 2010).

Els seguiments realitzats mostren una molt gran fluctuació interanual de cadascun dels nuclis d'Stachys maritima, com es pot constatar a la Taula 5. Les causes dels augments i descensos en els censos son múltiples. En primer lloc, el substrat sorrenc on creix aquesta espècie és extremadament mòbil, fet que pot provocar el soterrament d'individus adults, que poden romandre en latència durant una o més temporades a conseqüència de moviments naturals (llevantades) o d'origen antròpic (aplanaments, transport, etc.) que, en general, reapareixen després de pertorbacions (llaurat de dunes, anivellament, trasllat de sorres, etc.) que afavoririen el rebrot dels rizomes enterrats. En segon lloc, la germinació de les llavors sembla produir-se de manera episòdica, generant esdeveniments esporàdics de gran reclutament, després de precipitacions adequades, cosa que permet inferir l'existència d'un banc de llavors a la sorra. Finalment, la pròpia mobilitat del substrat, així com l'altíssima pressió antròpica de les localitats on es troba Stachys maritima, poden ser causa de desaparició de molts dels individus (trepig, aixafament, arrabassament, etc.), associada o no a la pèrdua de qualitat de l'hàbitat (artificialització $i$ nitrificació del medi, competència amb espècies invasores), així com, contràriament, l'estabilització excessiva del substrat: el declivi demogràfic de diverses poblacions va associada a la inexistència de pertorbació i l'entrada d'espècies banals competidores a l'hàbitat dunar (algunes de caràcter invasor o escapades de zones enjardinades). Les dades disponibles (a manca d'estudis demogràfics individualitzats i de viabilitat poblacional projectada, que caldria emprendre) no permeten definir el funcionament de la dinàmica metapoblacional d'Stachys maritima, que compta amb nuclis més o menys estables d'individus que presenten explosions demogràfiques ocasionals. Les dades obtingudes indiquen que les oscillacions estan més relacionades amb fenòmens locals a les poblacions (pertorbacions dels sistemes dunars, accions antròpiques) que amb factors d'àmbit general (per exemple climàtics: sembla no haver-hi relació entre els règims de precipitacions anuals i les variacions de censos). No obstant, el propi fet de que el nombre d'individus sigui tan fluctuant comporta un major risc d'extinció estocàstica a mesura que augmenta la fragmentació poblacional i disminueix la mida de les poblacions. Els propis criteris de la UICN (2001) reconeixen les fortes oscil·lacions demogràfiques com a causa d'amenaça.

De tots els nuclis seguits durant aquest període, un es pot considerar, a hores d'ara, provisionalment extingit (Sant Martí d'Empúries, nucli 1), ja que no s'hi ha pogut trobar cap individu des de l'any 2003. L'augment progressiu de la intensitat de recerca d'Stachys maritima al territori català ha produït un increment de la quantitat de poblacions conegudes. És possible, doncs, que en els propers anys, si es continua amb la dinàmica de treball de les últimes dècades, puguin aparèixer nous nuclis d'aquesta espècie, bé al territori on ja és ben co-

Figura 6. Vistes generals d'algunes de les poblacions d'Stachys maritima: (A), platja de la Rovina; (B), desembocadura del Fluvià; (C), Sant Martí d'Empúries, nucli 2; (D), massís del Montgrí, nucli 1; (E), massís del Montgrí, nucli 2; (F), "Radio Liberty" abans de la retirada de les antenes; $(\mathrm{G})$, apartaments platja de Begur; $(\mathrm{H})$, viver de Regencós [Fotografies: (A), (B), (C), (D), (F) i (G), J. López-Pujol; (E) i (H), S. Massó]. 

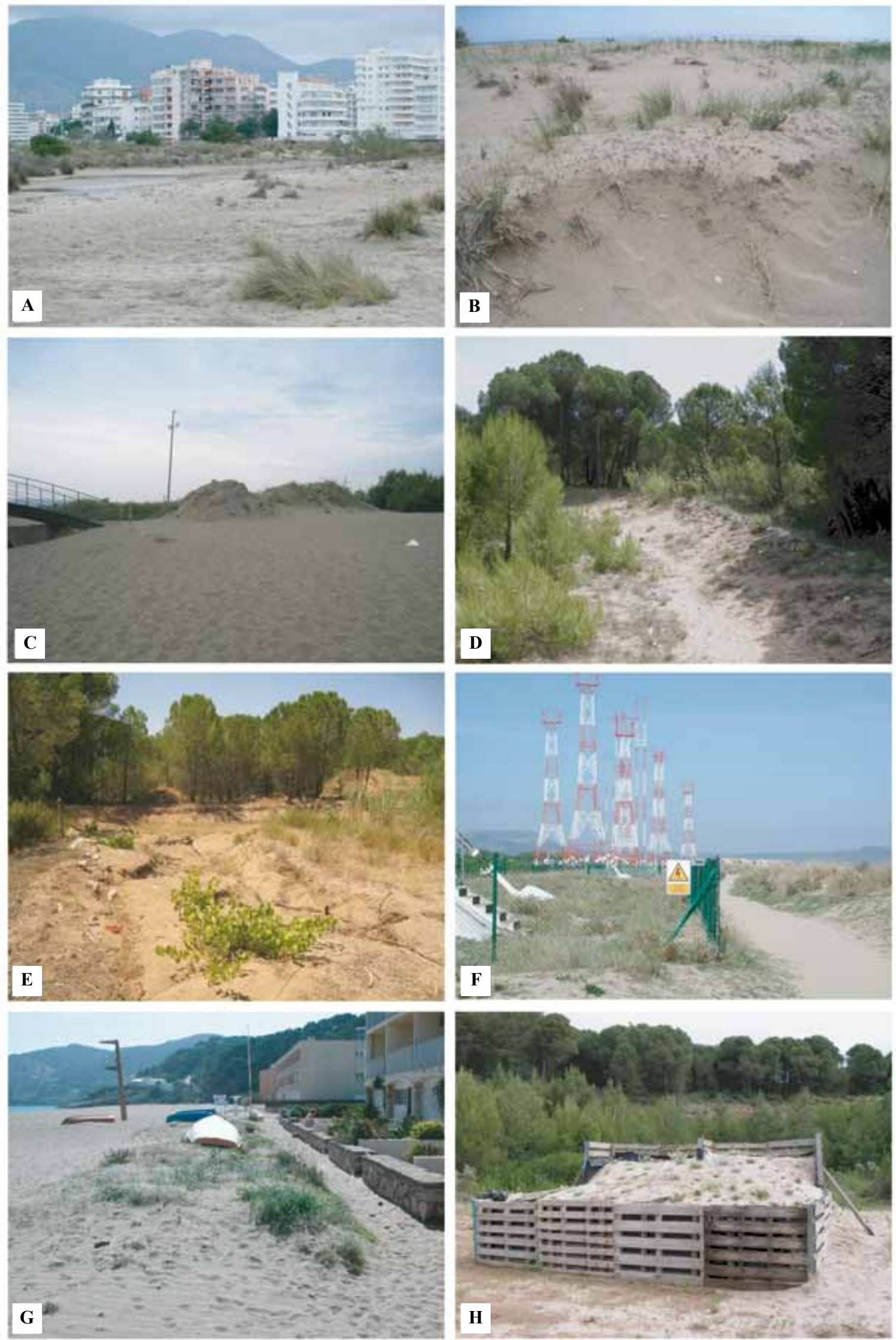
neguda (l'Empordà), bé a d'altres indrets on havia estat citada històricament (Barriocanal \& Blanché, 2002), tal i com va passar en el cas del Prat de Llobregat. De fet, enguany (2010) s'ha trobat una nova localitat a Can Comes (terme municipal de Castelló d'Empúries, Alt Empordà), amb tan sols dos individus (J. Font, com. pers.). En aquest sentit, és necessari potenciar una activitat exploratòria reiterada (any rere any), especialment tenint en compte les grans fluctuacions poblacionals que pot patir aquesta espècie.

És molt important tenir en compte, de cara a l'aplicació de mesures correctives o preventives per garantir la protecció d'Stachys maritima, aquesta fluctuació de les mides poblacionals. Això suposa, en primer lloc, que no es pot donar definitivament per extingit un nucli fins molts anys després de l'última cita constatada (com ha quedat ben palès a la població del Baix Llobregat), cosa que ja indica la moratòria de 50 anys establerta per la UICN (2001). Alhora, també cal tenir present que la presència d'un nombre elevat d'individus en un nucli un determinat any no és garantia del bon estat de conservació de la població; és d'esperar que a conseqüència d'una pertorbació puntual de l'hàbitat es produeixin explosions demogràfiques, però la continuïtat en el temps d'aquestes pertorbacions pot limitar la supervivència d'aquests individus. En aquests moments, considerem imprescindible el desenvolupament d'estudis demogràfics en detall i a llarg termini d'aquesta espècie, per tal de conèixer les taxes de mortalitat i reclutament i els valors de MVP (minimum viable population) (Iriondo et al., 2009).

\section{Diversitat genètica}

Les poblacions d'Stachys maritima estudiades presenten un nombre baix d'al·lels (entre 20 i 23; Taula 3), i tan sols quatre dels loci analitzats han resultat ésser polimòrfics (Aco-1, Idh-2, Mdh-2 i $6 P g d-1)$. En conseqüència, en un total de 217 individus analitzats, tan sols s'han identificat 14 genotips multi-locus diferents, i alguns dels nuclis estudiats son monomòrfics per a tots els loci.

Els valors de diversitat genètica són molt reduïts per a tots els nuclis d'Stachys maritima estudiats, fins i tot nuls a quatre d'elles (Taula 4), assolint valors semblants les poblacions naturals i les artificials. La comparació entre els valors d'heterozigositat observada $\left(H_{\mathrm{o}}\right)$ i heterozigositat esperada $\left(H_{\mathrm{e}}\right)$ indiquen un dèficit d'heterozigots que resulta significatiu per alguns loci (Taula 6). La divergència genètica entre totes les poblacions d'Stachys maritima s'ha quantificat computant el paràmetre $F_{\mathrm{ST}}$ un indicador de la diferenciació genètica entre les poblacions. El valor mitjà de $F_{\mathrm{ST}}$ és molt alt $(0,671 ; 0,669$ excloent les poblacions artificials), indicant que una fracció molt important de la variabilitat genètica total del tàxon $(67,1 \%)$ és atribuïble a la diferenciació entre les poblacions, i que només al voltant del $33,9 \%$ de la diversitat es troba dins de les poblacions, reflectint un flux de gens molt limitat entre aquestes.

Els valors de diversitat genètica d'Stachys maritima són baixos en comparació amb els valors de referència per a espècies vegetals amenaçades de la Mediterrània $\left(P=23,7 \%, A=1,49\right.$ i $H_{\mathrm{e}}=0,094$; López-Pujol et al., 2006). La destrucció del seu hàbitat natural (descrita àmpliament a Barriocanal \& Blanché, 2002) hauria conduït a una erosió genètica fruit de la fragmentació poblacional i de l'existència de colls d'ampolla, traduïda tant en una pèrdua d'al·lels com en un increment de l'endogàmia. A més, les severes fluctuacions poblacionals que es detecten en aquesta espècie poden contribuir encara més a reduir el nivell de diversitat genètica, atès a que disminueixen significativament la mida poblacional efectiva $\left(N_{\mathrm{e}}\right)$ (Carroll \& Fox, 2008). No existeix una correlació evident entre els nivells de diversitat i la mida poblacional atès que els resultats se situen a la banda més baixa de variació genètica i, de tan empobrits, no tenen prou resolució per $\mathrm{a}$ indicar diferències significatives. No obstant això, és cert que les poblacions de mida més petita solen presentar valors de diversitat nul·la i que són constituïdes per un únic genotip multilocus, en part explicable pel creixement clonal de l'espècie i que algunes de les poblacions amb més individus presenten nivells de diversitat només lleugerament superiors, la qual cosa confirma que realment molts nuclis es troben per sota d'una mida poblacional viable (MVP). Hi ha poblacions molt petites, com ara GTER (desembocadura del Ter), que presenten nivells de diversitat $\left(P=10,0 ; A=1,1\right.$ i $\left.H_{\mathrm{e}}=0,034\right)$ equiparables a poblacions més grosses que es poden interpretar com a diversitat romanent de moments amb mides poblacionals més importants i que demostrarien 

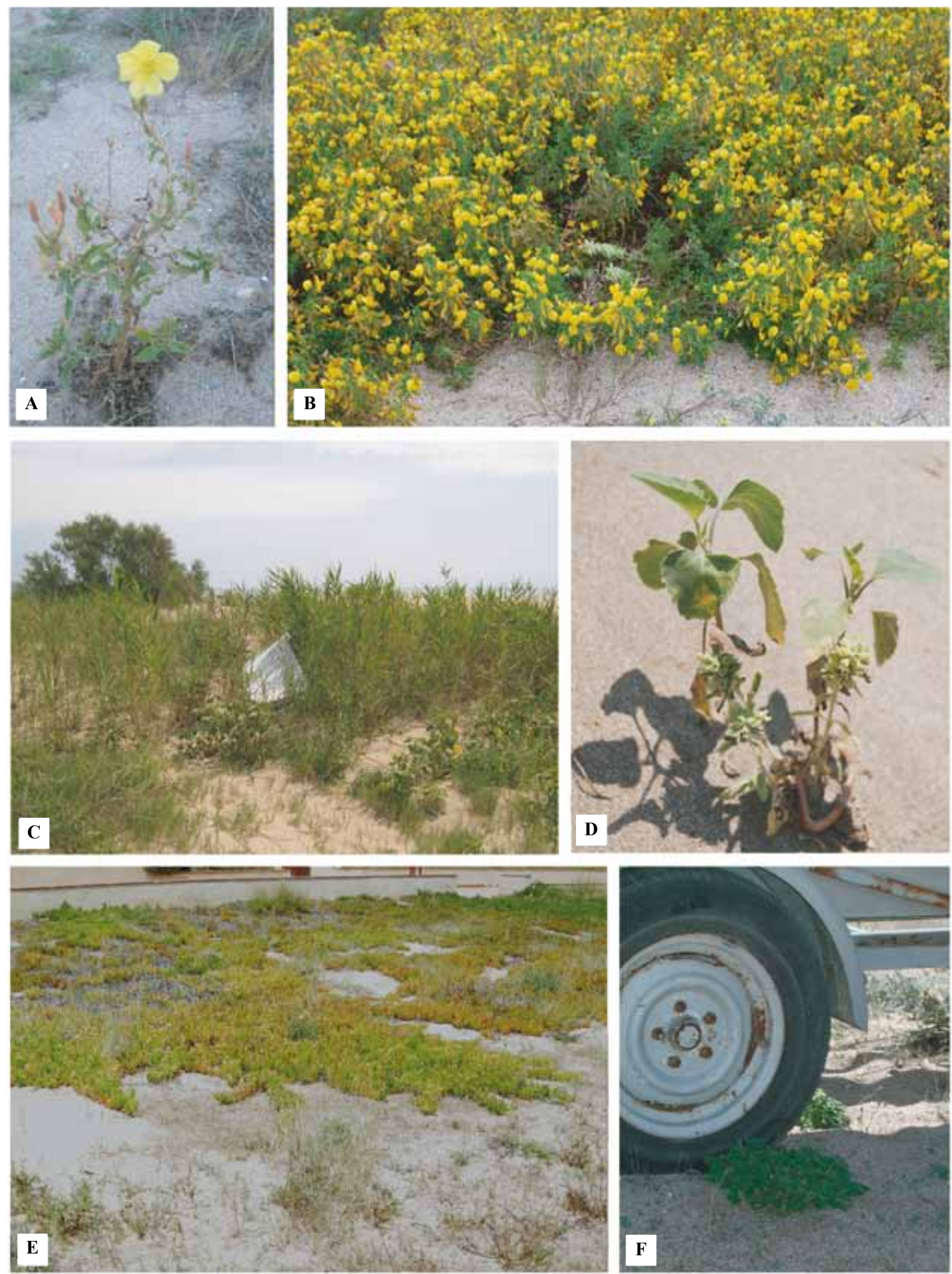

Figura 7. Amenaces d'Stachys maritima en les diferents poblacions: (A), Oenothera biennis a la platja de la Rovina; (B), estat de la platja de la Rovina l'estiu de 2008, amb una invasió d'Ononis natrix; (C), Arundo donax i deixalles a la desembocadura del Fluvià; (D), Xanthium strumarium subsp. italicum sobre un individu d'Stachys maritima a Sant Martí d'Empúries; (E), Carpobrotus spp. als apartaments de la platja de Pals; (F), roda d'un remolc damunt un individu al varador de la platja de Pals. [Fotografies: (A), (B), (C), (D) i (E), S. Massó; (F), J. López-Pujol]. 


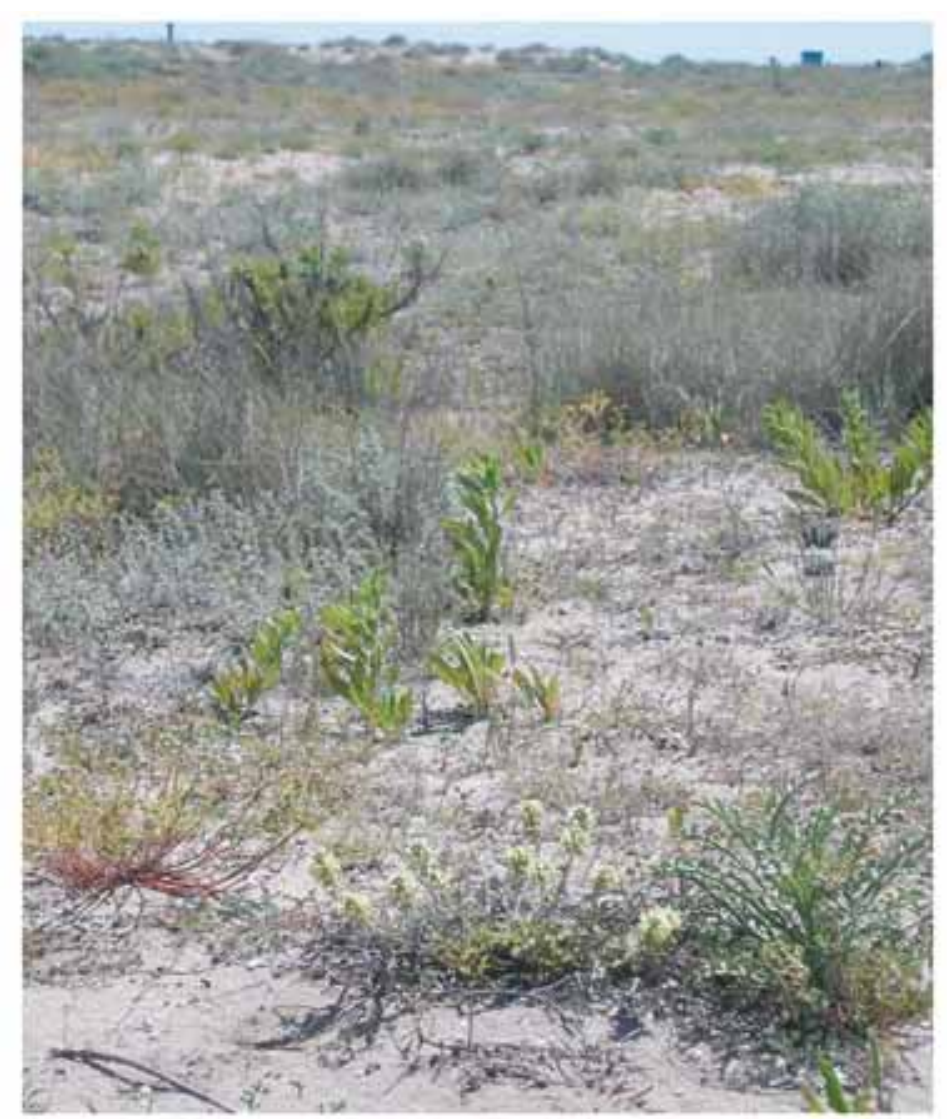

Figura 8. Distribució esquemàtica de genotips a la població del Prat, 2006-2009 (PPRA, parcel-la de 5 x $3 \mathrm{~m}$ ). Blau: genotip 1 (homozigot Aco-2); vermell: genotip 2 (heterozigot $A c o-2$ ); groc: únic individu descobert el 2006 (aparentment mort el 2008) i que es pot observar a la fotografia. El cercle verd representa un individu d'olivarda (Dittrichia viscosa) que s'usa com a referència [Fotografia: C. Blanché].
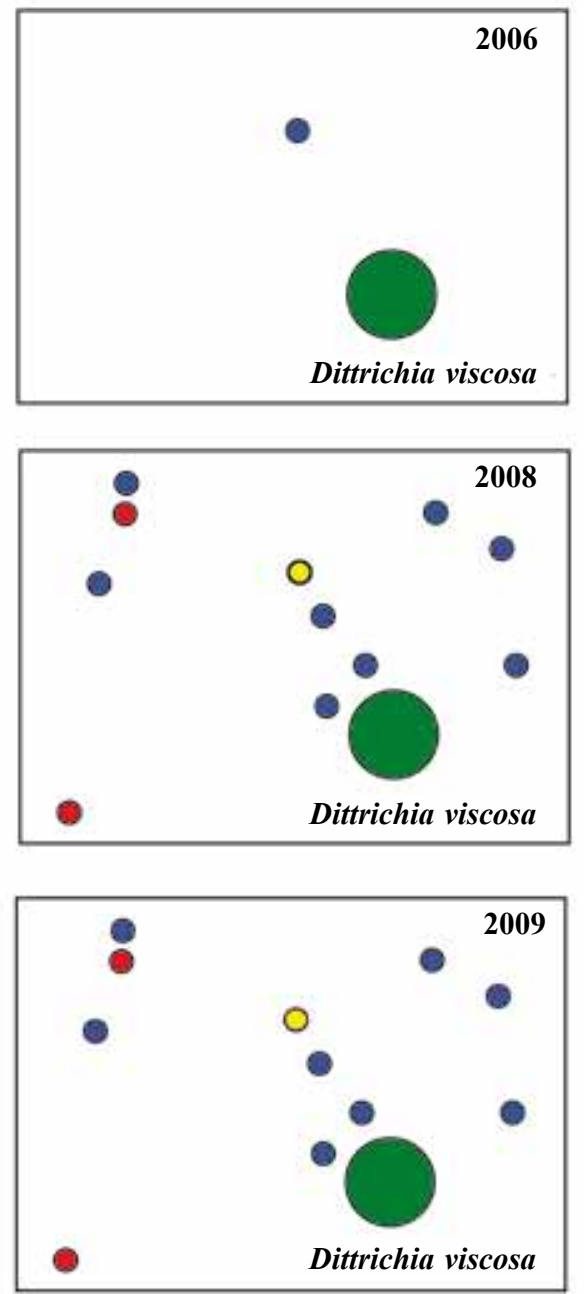

una fragmentació relativament recent. Algunes de les poblacions artificials de mida poblacional més gran presenten també nivells de diversitat molt baixos, interpretables com a resultat d'efectes fundadors, amb posterior explosió demogràfica però sense aportació de nous genotips.

La diferenciació genètica entre les poblacions catalanes d'Stachys maritima presenta un valor molt elevat $\left(G_{\mathrm{ST}}=0,671\right)$, d'entre els més alts reportats mai per a espècies vegetals mediterrànies (López-Pujol et al., 2006). La fragmentació de poblacions, així com la desaparició d'algunes localitats ben documentades (Barriocanal \& Blanché, 2002), haurien afavorit la interrupció del flux gènic, contribuint així als altíssims nivells de divergència detectats per a l'espècie. Igualment, aquestes dades suggereixen que el possible funcionament com a metapoblacions de nuclis d'individus interconnectats ha de tenir un abast limitat, reduït a àrees coincidents amb les badies naturals. Hi ha evidències, en d'altres espècies del litoral mediterrani, que l'estructuració de la diversitat genètica coincideix amb les àrees naturals establertes pels corrents marins (Gandour et al., 2008) i que el sistema de dispersió de les granes pot tenir un efecte determinant en l'estructura genètica. Aquests autors justifiquen una diferenciació interpoblacional del $37 \%$ en Cakile maritima Scop. (inferior a la reportada aquí per a Stachys maritima) en base, precisament, als patrons de dispersió de fruits coincidents amb la circulació dels corrents marins. Hem iniciat estudis, actualment en curs, per tal de verificar aquesta hipòtesi en Stachys maritima. 
Taula 6. Valors de l'índex de fixació $(F)$ per a tots els loci polimòrfics a les poblacions d'Stachys maritima. Per a la població PPRA no es té en compte el locus Aco-2.

\begin{tabular}{|c|c|c|c|c|c|c|c|c|c|c|c|c|}
\hline Locus & PROV & FLU & SME1 & SME2 & MON1 & GTER & PPAL & SPUN & PPRA & MON2 & URBP & REGE \\
\hline Aco-1 & - & - & - & - & - & $-0,077 \mathrm{~ns}$ & $0,466^{* * *}$ & - & - & - & - & - \\
\hline$I d h-2$ & - & $0,709 *$ & - & - & - & - & - & - & - & - & - & - \\
\hline$M d h-2$ & $0,556^{* *}$ & - & - & - & - & - & $-0,014 \mathrm{~ns}$ & - & - & - & - & - \\
\hline $6 P g d-2$ & - & - & - & - & - & $1,000^{* *}$ & $0,695^{* * *}$ & $-0,152 \mathrm{~ns}$ & - & $0,426^{*}$ & - & $1,000^{* * *}$ \\
\hline
\end{tabular}

\section{Seguiment genètic (Genetic monitoring)}

Els coneixements de la dinàmica poblacional d'aquesta espècie adquirits durant els darrers anys (sobretot l'existència de fluctuacions molt significatives en el nombre d'individus dels diferents nuclis poblacionals), així com la troballa de nous nuclis des de l'any 2008 (nuclis 3 i 4 del massís del Montgrí, així com dels individus de l'interior de l'antic recinte de "Radio Liberty" o la petita població de la platja de Can Comes), fan necessària una reconsideració d'aquests valors i la seva interpretació (tant els de diversitat genètica a nivell d'espècie com els de divergència genètica interpoblacional). En el cas d'una espècie amb una dinàmica poblacional tan fluctuant, les mostres poblacionals, en estar preses en anys diferents, no serien estrictament comparables o, si més no, caldria tenir en compte el moment de l'oscillació en què han estat capturades. Caldria conèixer quina és la distribució en el temps, i no només en l'espai, de la diversitat genètica, raó per la qual convindria fer els estudis de diversitat genètica a totes les poblacions el mateix any, i repetir el mateix esquema durant diferents anys per tal de poder inferir l'efecte de les fluctuacions demogràfiques en la variabilitat genètica a nivell poblacional. Aquests tipus d'estudis, que podrien establir la base per una monitorització genètica de l'espècie (genetic monitoring, Schwartz et al., 2006) són recomanats avui ja com a instrument estàndard en genètica de la conservació, d'un gran interès científic i d'enorme utilitat per a la correcta gestió d'Stachys maritima.
S'ha dut a terme una prova pilot de seguiment genètic a la població de la Platja del Prat, amb la col-laboració del Jardí Botànic Marimurtra i el Consorci del Delta del Llobregat (Martinell et al., 2009). Una parcel-la de $5 \times 3 \mathrm{~m}$, on va ser detectat l'any 2006 el primer individu retrobat al Baix Llobregat, va ser objecte de seguiment demogràfic conjuntament amb la identificació dels genotips durant tres anys (2006-2008). Els resultats es mostren a la Fig. 8. L'únic individu retrobat corresponia al genotip 1 (homozigot per a Aco-2). L'any següent, el nucli contenia 11 individus; d'aquests, dos corresponent al genotip 2 (heterozigot per a $\mathrm{Aco}-2$ ) Si assumim els 10 individus apareguts al cens del $2008 \mathrm{com}$ a originats per autofecundació de l'únic individu preexistent, aquests haurien de presentar el mateix genotip. Per tant, el genotip 2 cal atribuir-lo a l'emergència a partir de llavors o de rizomes dorments, preexistents però no emergits. Això permet establir la hipòtesi que el cens d'individus emergits podria ser únicament una part de la població, de manera que una part significativa pot restar com a reservori sota terra. L'existència d'una fracció significativa de la diversitat genètica en forma de propàguls al sòl com a banc de granes o de rizomes dorments ha estat reportada en múltiples ocasions (vegeu, per exemple Lundemo et al., 2009) i permet explicar els fenòmens de reclutament episòdic observats, precisament a partir d'aquest banc, que en Stachys maritima podria ser prou important i que convindria avaluar convenientment.

Una altra aplicació de la pràctica del seguiment genètic de manera habitual és la planificació de 
les accions de reforçament o de translocació amb base científica. Dacosta et al. (2008) donaven a conèixer la iniciativa de reforçament de la població de "Radio Liberty" (Pals) a partir dels individus localitzats a Regencós. Tot i que hom disposava de protocols per a l'estudi genètic de l'adequació de l'acció, no es va dur a terme cap estudi previ. Les dades aportades més amunt (Taula 3) confirmen la idoneïtat final del reforçament, atesa l'equivalència genètica entre els individus d'origen i la població natural de destí, però podria no haver estat així, amb greu perill d'outbreeding depression (Fenster \& Dudash, 1994), vista l'estructuració de la diversitat en zones $\mathrm{amb}$ forta divergència genètica. Tampoc s'ha dut a terme cap seguiment genètic posterior a la reintroducció, de manera que s'ha perdut una oportunitat excepcional d'obtenir dades essencials sobre supervivència, fitness i nivells de diversitat/ heterozigosi, tan difícils d'obtenir en espècies rares $i$ amenaçades (López-Pujol et al., 2008).

Aquests exemples posen de manifest la conveniència d'acoblar el seguiment genètic al seguiment demogràfic de manera rutinària per tal de garantir una més gran eficàcia de les accions de conservació i, al mateix temps, generar nou coneixement que pugui retroalimentar la planificació i l'execució de les mesures que s'adoptin (Schwartz et al., 2006).

\section{CONCLUSIONS}

Stachys maritima és una de les espècies que es troba en un major risc d'extinció a Catalunya, a causa, principalment, de la vulnerabilitat del seu hàbitat amb una regressió documentada molt important de l'àrea d'ocupació i de l'extensió de presència (Barriocanal \& Blanché, 2002): la seva àrea de distribució i el nombre de poblacions ha disminuilt ostensiblement durant el darrer segle, i els nuclis actualment existents presenten un reduït nombre d'individus $i$ unes fluctuacions poblacionals molt marcades, que contribueixen a augmentar la seva situació de risc.

En els últims anys, el coneixement científic sobre aquesta espècie ha augmentat notablement fruit de l'esforç dut a terme tant per diversos grups d'investigació com per personal lligat a les administracions (agents forestals, gestors d'espais protegits, etc.), tot i que encara manquen estudis en detall de la seva dinàmica poblacional, estudis genètics més acurats (idealment, un seguiment genètic) i un estudi sistemàtic de la seva biologia reproductiva, així com desenvolupar uns protocols de germinació i de cultiu eficients o dur a terme experiments per la seva possible reintroducció o reforçament poblacional, és dir generar el coneixement necessari per a la producció ex-situ, de cara al desenvolupament d'un pla de recuperació, tal i com és imperatiu segons el Catàleg de Flora Amenaçada de Catalunya (DOGC, 2008).

Per altra banda, en els últims anys s'han desenvolupat diverses accions amb l'objectiu de conservar aquesta espècie, fruit d'iniciatives aïllades. Així, durant alguns anys, els òrgans gestors de l'EIN Basses d'en Coll han dut a terme accions de senyalització i d'ordenació de l'accés a les platges de la zona de Pals, de correcció de pràctiques de jardineria per tal d'evitar l'expansió de Carpobrotus spp., de seguiment poblacional o d'educació ambiental que, semblantment, s'han realitzat també al Parc Natural dels Aiguamolls de 1'Empordà. El Parc Natural Montgrí-Medes-Baix Ter, de recent creació, ha inclòs àrees amb Stachys maritima a la seva zona de gestió i l'espècie ha estat inclosa entre els tàxons que mereixeran accions de conservació segons els objectius del Parc Natural. Per la seva banda, la delegació de Medi Ambient i Habitatge de la demarcació de Girona, amb la col-laboració d'investigadors de la Universitat de Girona, realitza tasques de seguiment $i$ vigilància de les poblacions i va promoure la creació d'un viver i la translocació d'individus amb destí a la platja de Pals, a partir dels individus descoberts a la sorrera de Regencós. El Consorci del Delta del Llobregat ha iniciat un seguiment detallat, a escala d'individu, de la població del Prat, amb la col·laboració del Jardí Botànic Marimurtra (que ha iniciat experiments de germinació i de cultiu i que conserva granes al seu banc de germoplasma) i de l'equip de recerca del BioC-Universitat de Barcelona-Institut Botànic de Barcelona (que participa en el seguiment demogràfic i l'estudi de diversitat genètica).

Tot i que totes aquestes iniciatives són valuoses contribucions per la preservació de l'espècie, seria necessari assegurar l'acció coordinada i el suport científic de totes elles, per tal d'evitar la duplicació d'esforços, afavorir la sinèrgia de diversos equips $i$ institucions compromesos i garantir la conservació a llarg termini i a totes les escales d'Stachys maritima, un dels "actius" més valuosos de la nostra flora. El 
marc genèric per a aquesta coordinació hauria de ser el Pla de Recuperació d'Stachys maritima, per al qual proposem, a partir de les dades aportades, les recomanacions següents:

1. Les mesures de conservació a incloure en el Pla de Recuperació haurien de contenir, associades, la condició d'experimentació científica de les accions que s'emprenguin, amb els corresponents estudis detallats de demografia i PVA (population viability analysis, anàlisi de viabilitat poblacional), seguiment genètic i de biologia reproductiva (longevitat, pol·linització, dispersió de granes), de manera que, al costat d'objectius de manteniment o de recuperació del nombre d'individus $i$ de poblacions (objectius biològics) s'hi incloguin objectius de coneixement que permetin orientacions de gestió adaptativa i de manipulació d'espècies amenaçades sobre les quals es coneix ben poc als països mediterranis.

2. A partir de les dades demogràfiques reportades, cal assajar experimentalment la pràctica de pertorbacions a les poblacions com a mesura que pot promoure l'emergència de propàguls (granes i rizomes dorments) no detectats per censos d'individus emergits $i$ que pot permetre atènyer mides poblacionals mínimament viables (MVP). Cal avaluar la bondat d'aquesta pràctica enfront del manteniment de sistemes dunars estabilitzats i no pertorbats que, en l'actualitat van associats al declivi poblacional i a l'ingrés d'espècies al·lòctones.

3. En paral·lel, cal un estudi detallat de la composició i estructura del banc de propàguls subterranis, així com la seva avaluació genètica. Atès que totes les localitats de l'espècie a Catalunya tenen una mida poblacional molt petita (i per tant molt amenaçades), el més adequat seria fer-ho en una parcellla experimental.

4. Les accions de restauració de vegetació dunar o fins i tot de creació de noves platges (per exemple a la nova desembocadura del Llobregat) haurien de contemplar la introducció de noves poblacions d'Stachys maritima, creades a partir del disseny de composició de genotips adequada i amb seguiment científic del procés d'instauració, propagació i persistència de les noves poblacions.

5. Per tal de garantir la disposició de material vegetal suficient, cal promoure els estudis ex-situ de germinació i de multiplicació clonal i de reproducció sexual, així com el manteniment de granes en banc de germoplasma.
6. A partir dels valors de diferenciació interpoblacional $\left(F_{\mathrm{ST}}\right)$, l'objectiu de conservar el $99 \%$ de la diversitat genètica total $(D V)$, seguint les estimacions de Hamrick et al. (1991; $n=\ln$ (1$\left.D V) / \ln F_{\mathrm{ST}}\right)$ suggereix la necessitat de conservar almenys $n=11$ poblacions (més del total existent a la Península Ibèrica), de manera que han de ser conservades totes les poblacions.

7. Atès que moltes poblacions se situen per sota de qualsevol estimació de mida mínima poblacional (MVP) per fer front a fenòmens estocàstics $o$ incidències demogràfiques $o$ genètiques $i$ que, a més, presenten nivells de diversitat genètica extremadament baixos, cal considerar la pràctica de reforçaments poblacionals. Puix que, al costat d'una estructuració molt marcada de la diversitat, existeixen identitats genètiques interpoblacionals elevades, abans de procedir a aquests reforçaments cal assajar experimentalment la mescla d'orígens de donadors genètics per incrementar la diversitat genètica (almenys als nivells de les poblacions més variables) i avaluar el possible risc d'outbreeding depression.

8. Seria recomanable la comparació de la diversitat genètica de les poblacions catalanes amb la d'altres regions on les poblacions mantinguin mides més grans i un menor grau de fragmentació i d'altres afectacions humanes, per tal de conèixer l'abast real de la depauperació genètica de l'espècie a casa nostra.

\section{AGRAÏMENTS}

A totes aquelles persones que durant els 10 anys de seguiment han col-laborat en el treball de camp. Molt especialment a Joan Font que ha aportat moltes dades de noves poblacions i ha fet censos d'algunes localitzacions. Part del treball prové de dades aportades dins el projecte AFA (Atlas de Flora Amenzada) de la SEBCP-MIMAM, així com d'un projecte per a l'estudi de la diversitat genètica de la població del Baix Llobregat (Jardí Botànic MariMurtra en conveni amb el Consorci per a la Protecció i Gestió dels Espais Naturals del Delta del Llobregat). Els estudis genètics de la resta de poblacions estudiades l'any 2008 i alguns dels censos durant el període 2008-2010 s'han finançat mitjançant el projecte CGL2007-60475/BOS del MEC.

\section{REFERÈNCIES BIBLIOGRÀFIQUES}

Barriocanal, C. 2005. La delicada situación de Stachys maritima en la Costa Brava. Quercus 237: 38-41.

Barriocanal, C. \& Blanché, C. 2002. Estat de conservació i 
C. BLANCHÉ, C. BARRIOCANAL, M. C. MARTINELL, S. MASSÓ \& J. LÓPEZ-PUJOL

propostes de gestió per a Stachys maritima Gouan (Labiateae) a la península ibèrica. Orsis 17: 7-20.

Carroll, S. P. \& Fox, C. W. (Eds.). 2008. Conservation biology. Evolution in action. Oxford University Press, New York.

Dacosta, J. M., Font, J., Carabús, M. P. \& Sanjuán, X. 2008. Actuació de conservació de Stachys maritima Gouan al Baix Empordà. I Jornades Catalanes de Conservació de Flora (Blanes, 2 i 3 de juny de 2008). Llibre de Resums: 62.

DOGC (Diari Oficial de la Generalitat de Catalunya). 2008. Decret 172/2008, de 26 d'agost, de creació del Catàleg de flora amenaçada de Catalunya. Diari Oficial de la Generalitat de Catalunya 5204: 65881-65895.

Fenster, C. B. \& Dudash, M. R. 1994. Genetic considerations for plant population restoration and conservation. In: Bowles, M. L. \& Whelan, C. J. (Eds.), Restoration of Endangered Species: Conceptual Issues, Planning and Implementation. Cambridge University Press, Cambridge: 34-62.

Gandour, M., Hessini, K. \& Abdelly, C. 2008. Understanding the population genetic structure of coastal species (Cakile maritima): seed dispersal and the role of sea currents in determining population structure. Genet. Res., Camb. 90: 167-178.

Gottlieb, L. D. 1982. Conservation and duplication of isozymes in plants. Science 216: 373-380.

Greuter, W., Burdet, H. M. \& Long, G. 1986. Med-Checklist, vol. 3. Conservatoire et Jardin Botaniques de la Ville de Genève, Genève.

Hamrick, J. L., Godt, M. J. W., Murawski, D. A. \& Loveless, M. D. 1991. Correlation between species traits and allozyme diversity: implications for conservation biology. In: Falk, D. A. \& Holsinger, K. E. (Eds.), Genetics and conservation of rare plants. Oxford University Press, New York: 75-86.

Hoyo, R. del, González, V. \& Valverde, A. 2006. Stachys maritima Gouan retrobada a les platjes del delta del Llobregat (Barcelona). Butll. Inst. Catalana Hist. Nat. 74: 95-96.

Ibáñez, N. 2006. Estudis sobre cinc herbaris històrics de l'Institut Botànic de Barcelona. Tesi Doctoral, Universitat de Barcelona.

Iriondo, J. M., Albert, M. J., Giménez Benavides, L., Domínguez Lozano, F. \& Escudero, A. (Eds.) 2009. Poblaciones en peligro: viabilidad demográfica de la flora vascular amenazada de España. Dirección General de Medio Natural y Política Forestal, Ministerio de Medio Ambiente y Medio Rural y Marino, Madrid.

Jefferies, R. L. \& Gottlieb, L. D. 1982. Genetic differentiation of the microspecies Salicornia europaea L. (sensu stricto) and S. ramosissima J. Woods. New Phytol. 92: 123-129.

Kephart, S. R. 1990. Starch gel electrophoresis of plant isozymes: a comparative analysis of techniques. Amer. J. Bot. 77: 693-712.

López-Pujol, J., Bosch, M., Simon, J. \& Blanché, C. 2006. Diversitat isoenzimàtica de la flora vascular silvestre dels Països Catalans. Butll. Inst. Catalana Hist. Nat. 74: 5-28.

López-Pujol, J., Orellana, M. R., Bosch, M., Simon, J. \& Blanché, C. 2003. Effects of habitat fragmentation on allozyme diversity and conservation status of the coastal sand dunes plant Stachys maritima (Lamiaceae) in the Iberian Peninsula. Plant Biol. 5: 504-512.

López-Pujol, J., Zhang, F.-M. \& Ge, S. 2008. No correlation between heterozygosity and vegetative fitness in the narrow endemic and critically endangered Clematis acerifolia
(Ranunculaceae). Biochem. Genet. 46: 433-445

Lundemo, S., Falathi-Anbaran, M. \& Stenölen, H. K. 2009. Genetic consequences of seed banks and implications for plant conservation. Conservation Genetics Conference: Integrating Population Genetics and Conservation Biology. ESF-NINA, 23-26 de maig de 2009, Trondheim.

Martinell, M. C., López-Pujol, J. \& Blanché, C. 2009. New and rediscovered populations of Stachys maritima in the Iberian Peninsula: Re-evaluation of its genetic diversity. Conservation Genetics Conference: Integrating Population Genetics and Conservation Biology. ESF-NINA, 23-26 de maig de 2009, Trondheim.

Molero, J., Rovira, A., Simon, J., Bosch, M., López-Pujol, J., Orellana, M. R., Barriocanal, C. \& Blanché, C. 2007. Stachys maritima Gouan. In: Bañares, A., Blanca, G., Güemes, J., Moreno, J. C. \& Ortiz, S. (Eds.), Atlas y Libro Rojo de la Flora Vascular Amenazada de España - Adenda 2006. Dirección General para la Biodiversidad - Sociedad Española de Biología de la Conservación de Plantas, Madrid: 30-31.

Odrzykoski, I. J. \& Gottlieb, D. 1984. Duplication of genes coding 6-phosphogluconate dehydrogenase (6PGD) in Clarkia (Onagraceae) and their phylogenetic implications. Syst. Bot. 9: 479-489.

Sáez, L., Aymerich, P. \& Blanché, C. 2010. Llibre vermell de les plantes vasculars endèmiques $i$ amenaçades de Catalunya. Argania Editio, Barcelona.

Scandalios, J. 1969. Genetic control of multiple molecular forms of enzymes in plants: a review. Biochem. Genet. 3: 37-79.

Schwartz, M. K., Luikart, G. \& Waples, R. S. 2006. Genetic monitoring as a promising tool for conservation and management. Trends Ecol. Evol. 22: 25-33.

Shields, C. R., Orton, T. J. \& Stuber, C. W. 1983. An outline of general resources needs and procedures for the electrophoretic separation of active isozymes from plant tissue. In: Tanksley, S. D. \& Orton, T. J. (Eds.), Isozymes in Plant Genetic and Breeding. Elsevier Science Publishers, Amsterdam: 443-468.

Soltis, D. E., Haufler, H., Darrow, D. \& Gastony, J. 1983. Starch gel electrophoresis of ferns: a compilation of grinding buffers, gel and electrode buffers and staining schedules. Amer. Fern J. 73: 9-27.

Swofford, D. L. \& Selander, R. B. 1989. BIOSYS-1: A computer program for the analysis of allelic variation in genetics. User's Manual. Department of Genetics and Development, University of Illinois, Urbana-Champaign.

UICN (Unión Internacional para la Conservación de la Naturaleza). 2001. Categorías y Criterios de la Lista Roja de la UICN: Versión 3.1. Comisión de Supervivencia de Especies de la UICN, Gland \& Cambridge.

Vallejos, E. 1983. Enzyme activity staining. In: Tanksley, S. D. \& Orton, T. J. (Eds.), Isozymes in plant genetics and breeding. Elsevier Science Publishers, Amsterdam: 469-516.

Wendel, F. \& Weeden, N. F. 1989. Visualization and interpretation of plant isozymes. In: Soltis D. E. \& Soltis P. S. (Eds.), Isozymes in plant biology. Dioscorides Press, Portland: 5-45.

Wright, S. 1951. The genetic structure of populations. Ann. Eugen. 15: 323-354.

Wright, S. 1965. The interpretation of population structure by $F$-statistics with special regard to systems of mating. Evolution 19: 395-420. 